January 2010

\title{
Take This House and Shove It: The Emotional Drivers of Strategic Default
}

Brent T. White

\section{Recommended Citation}

Brent T. White, Take This House and Shove It: The Emotional Drivers of Strategic Default, 63 SMU L. REV. 1279 (2010)

https://scholar.smu.edu/smulr/vol63/iss4/6

This Article is brought to you for free and open access by the Law Journals at SMU Scholar. It has been accepted for inclusion in SMU Law Review by an authorized administrator of SMU Scholar. For more information, please visit http://digitalrepository.smu.edu. 


\title{
Take This House and Shove It: The Emotional Drivers of Strategic Default
}

\author{
Brent T. White*
}

An increasingly influential view is that strategic defaulters make a rational choice to default because they have substantial negative equity. This article, which is based upon the personal accounts of over 350 individuals, argues that this depiction of strategic defaulters as rational actors is woefully incomplete. Negative equity alone does not drive many strategic defaulters' decisions to intentionally stop paying their mortgages. Rather, their decisions to default are driven primarily by emotion-typically anxiety and hopelessness about their financial futures and anger at their lenders' and the government's unwillingness to help. If the government and the mortgage industry wish to stem the tide of strategic default, they must address these emotions.

Because emotions are primary, however, principal reductions may not be necessary. Rather, many underwater homeowners simply need some reason to feel less apprehensive about the financial consequences of continuing to pay their underwater mortgages. One possible way to provide this comfort would be a "rent-based loan program," allowing underwater homeowners to refinance their entire balances to interest rates that would bring their mortgage payments in line with the rental costs of comparable homes. A rent-based approach would relieve many underwater homeowners' financial anxieties and would likely be enough alone to stem the tide of strategic default.

* Associate Professor of Law, James E. Rogers College of Law, University of Arizona. I would like to thank Marc Miller, Eric Posner, Susan Bandes, Gregory Crespi, Barbara Atwood, Kathy Barnes, Jean Braucher, Toni Massaro, Barak Orbach, and David Marcus for their comments and suggestions. I would also like to thank Melanie Rainer and Erick Gjerdingen for their invaluable research assistance. Above all, I would like to thank the hundreds of homeowners who voluntarily shared their stories and made this article possible.

This article extensively quotes informal e-mail communications between the author, giving the personal accounts of over 350 unsolicited individuals. In order to preserve the unique voices of the contributors and to preserve anonymity, material quoted from these emails was not edited and the senders' identities have been omitted; it is reproduced in this article exactly as it was submitted in the original e-mail. See infra note 35. 
Table of Contents

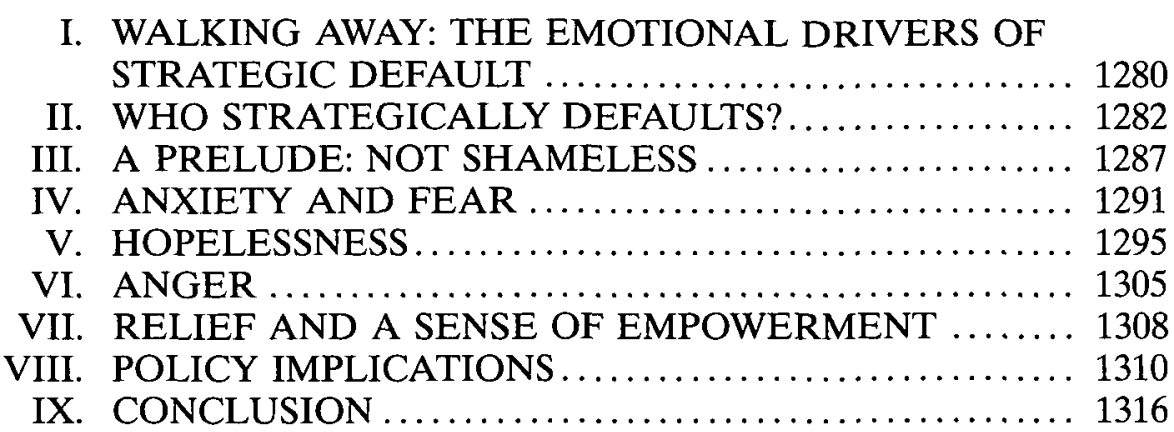

\section{WALKING AWAY: THE EMOTIONAL DRIVERS OF STRATEGIC DEFAULT}

A growing number of underwater homeowners have decided to intentionally stop paying their mortgages. ${ }^{1}$ Some deride such "strategic defaulters" as irresponsible, and others laud them as financially astute. ${ }^{2}$ But whether they are portrayed as repugnantly immoral or sensibly prudent, these individuals are generally seen as making a calculated economic decisions to let go of their homes. ${ }^{3}$ They are thought to have set their emotions aside, added up default's costs and benefits, and acted upon the results. Even those who condemn them for

1. See, e.g., Paola Sapienza \& Luigi Zingales, The Results: Wave VI, FInANCIAL Trust IndeX (Chicago Booth/Kellog School, Apr. 30, 2010), http://www.financialtrust index.org/resultswave6.htm ("The percentage of foreclosures that were perceived to be strategic was 31 percent in March 2010, compared to 22 percent in March 2009."); ExPERian-Oliver Wyman, Market Intelligence Report: Understanding Strategic DeFault in Mortgages Part 1 4, 10 (2009) (on file with author) (estimating a 128\% increase in the number of strategic defaults from 2007 to 2008 and finding that "from 2005 to 2008 , the number of strategic defaulters went up by 68 times in California and by 46 times in Florida"); David Streitfeld, No Aid or Rebound in Sight, More Homeowners Just Walk Away, N.Y. TImes, Feb. 3, 2010, at A1 (discussing this trend); 2010 Predictions from Shiller, Blinder, Rajan and More, WALL ST. J. (Jan. 5, 2010, 5:00 AM), http://blogs.wsj.com/ economics/2010/01/05/2010-predictions-from-shiller-blinder-rajan-and-more/ (quoting Robert Shiller as predicting in 2010 that "[s]trategic default on mortgages will grow substantially over the next year, among prime borrowers, and become identified as a serious problem. The sense that 'everyone is doing it' is already growing, and will continue to grow, to the detriment of mortgage holders").

2. See, e.g., Kenneth Harney, The Nation's Housing: Walking Away from a Mortgage, Wash. Post, Nov. 28, 2009, at E1 (quoting Fannie Mae spokesman Brian Faith saying "there's a moral dimension to this as homeowners who simply abandon their homes contribute to the destabilization of their neighborhood and community"); John D. Geanakoplos \& Susan P. Koniak, Op-Ed., Matters of Principal, N.Y. TIMEs, Mar. 5, 2009, at A31 (arguing that strategic defaulters "are not evil or irresponsible; they are defaulting because . . . it is the economically prudent thing to do"); Roger Lowenstein, The Way We Live Now: Walk Away from Your Mortgage!, N.Y. TIMES, Jan. 10, 2010, at MM15 (arguing that strategic default can be a wise financial choice); Luigi Zingales, The Menace of Strategic Default, CiTY J., Spring 2010, at 47-51 (arguing that strategic default is morally reprehensible and a social menace).

3. See, e.g., Zingales, supra note 2; Harney, supra note 2; Lowenstein, supra note 2; Geanakoplos \& Koniak, supra note 2. 
putting their self-interests ahead of the common good generally concede that strategic defaulters made sound economic decisions. ${ }^{4}$ As one interested observer noted, an "increasingly influential and empirically-supported view is that homeowners can afford the payment but make a rational choice to default, because the value of the mortgage substantially exceeds the value of their home." 5

This article, which is based upon the personal accounts of over 350 individuals, argues that this depiction of strategic defaulters as homo economicus is woefully incomplete. These accounts suggest that strategic default is not in many cases the triumph of rationality over emotion. While strategic default is frequently a rational economic choice for underwater homeowners, if rationality were the driving force, most strategic defaulters would walk away much sooner than they actually do. Instead, most strategic defaulters don't walk away until they are more than fifty percent underwater. Moreover, though negative equity plays an important role, many homeowners' decisions to strategically default-like the decisions of the majority of homeowners to keep paying their underwater mortgages ${ }^{6}$-are driven primarily by emotion.

The fact that strategic default is driven by emotion matters. It matters because if the assumption that strategic defaulters are making purely "economic decisions" is wrong, then dealing with strategic default in purely economic terms is likely to produce mixed, and perhaps unintended, results. If the government and the mortgage industry wish to prevent strategic default, then they need to understand the decision-making processes of underwater homeowners who intentionally stop paying their mortgages. As it turns out, strategic defaulters aren't necessarily more rational than other homeowners, nor are they free, as a class, from guilt or shame about defaulting. Rather, many strategic defaulters feel great anxiety about their financial situations, an overwhelming sense of hopelessness, and anger that their lenders and the government have refused to help. These emotions drive them to default.

Thus, if the government and the mortgage industry wish to reduce the incidence of strategic default, they must address these emotions, hope-

4. See, e.g., Liz Pulliam Weston, Are You Foolish to Pay Your Mortgage?, MSN MONEY (Dec. 9, 2009), http://articles.moneycentral.msn.com/Banking/HomeFinancing/ weston-should-you-walk-away-from-your-home.aspx?page=1 (conceding that strategic default may be rational, but arguing that it is "wrong, wrong, wrong").

5. Alex Edmans, The Responsible Homeowner Reward: An Incentive-Based Solution to Strategic Mortgage Default 2 (University of Pennsylvania, Wharton School of Business, Working Paper 2010), available at http://ssrn.com/abstract=1631928 ("Defaulting on their loan is an active and conscious decision: while they forfeit their home, they rid themselves of a mortgage liability of even greater value. The source of the problem is the homeowner's balance sheet: since he has negative equity in his home, it is not worth keeping it by paying the mortgage.").

6. See Brent T. White, Underwater and Not Walking Away: Shame, Fear and the Social Management of the Housing Crisis, 45 W AKE FOREST L. REv. (forthcoming Fall 2010), available at $\mathrm{http}: / /$ papers.ssrn.com/sol3/papers.cfm?abstract_id=1494467 (arguing that guilt, shame, and fear rather than rational economic considerations drive many underwater homeowners' decisions to continue paying their mortgage). 
fully in positive ways. Both the mortgage industry and the federal government have, so far, failed to do so. Worse, some lenders' loanmodification processes actually fuel the hopelessness and anger of underwater homeowners, as they seem designed to wear homeowners down and to ensure that no one who might otherwise pay the mortgage gets a loan modification. Similarly, the federal government's approach of assisting only underwater homeowners "at risk of imminent default"7 induces anger in those who feel unfairly left out while the "less deserving" get help.

In short, by failing to tend to the emotional drivers of strategic default, both the mortgage industry and the federal government might actually be contributing to, rather than constraining, its growth.

\section{WHO STRATEGICALLY DEFAULTS?}

In the face of growing concern over strategic default by underwater homeowners, several recent studies have attempted to identify the types of individuals who are most likely to strategically default as well as the economic conditions that drive them to do so. ${ }^{8}$ Some of what has emerged from these studies has been surprising.

For example, these studies have shown that the elderly, ${ }^{9}$ the highly educated, ${ }^{10}$ and those with high-credit scores are among the most likely to strategically default. ${ }^{11}$ This, of course, runs counter to the narrative that people who walk away from their homes somehow failed to internalize the values of personal responsibility and promise-keeping held dearly by prior generations. ${ }^{12}$ Nor does it support the notion that people who walk

7. Press Release, U.S. Dep't of the Treasury, Making Home Affordable: Updated Detailed Program Description (Mar. 4, 2009), http://www.ustreas.gov/press/releases/reports/housing_fact_sheet.pdf.

8. See, e.g., EXPERIAN-Oliver WyMAN, supra note 1, at 4-5; Christopher L. Foote, Kristopher Gerardi \& Paul S. Willen, Negative Equity and Foreclosure: Theory and Evidence, 64 J. of Urban Econ. 234, 234-35 (2008); Patrick Bajari, Chenghuan Sean Chu \& Minjung Park, An Empirical Model of Subprime Mortgage Default From 2000 to 2007 (Nat'l Bureau of Econ. Research, Working Paper No. 14625, 2010); Neil Bhutta, Jane Dokko \& Hui Shan, The Depth of Negative Equity and Mortgage Default Decisions 21 (Fed. Res. Bd. of Governors, Working Paper No. 35, 2010); Ethan Cohen-Cole \& Jonathan Morse, Your House or Your Credit Card, Which Would You Choose? Personal Delinquency Tradeoffs and Precautionary Liquidity Motives 3-5 (University of Maryland \& Fed. Res. Bank of Bos., Working Paper 2009); Andra C. Ghent \& Marianna Kudlyak, Recourse and Residential Mortgage Default: Theory and Evidence from U.S. States 5 (Fed. Res. Bank of Richmond, Working Paper No. 09-10R, 2010); Luigi Guiso, Paola Sapienza \& Luigi Zingales, Moral and Social Constraints to Strategic Default on Mortgages (Nat'l Bureau of Econ. Research, Working Paper No. 15145, 2009).

9. Guiso, Sapienza \& Zingales, supra note 8, at 19 (finding that the elderly were about six percentage points less likely to believe that strategic default is morally unacceptable).

10. Id. (finding that the highly educated were eight percentage points less likely to believe that strategic default is morally unacceptable).

11. See EXPERIAN-Oliver WyMAN, supra note 1, at 14.

12. See, e.g., Lowenstein, supra note 2 ""Such voluntary defaults are a new phenomenon. Time was, Americans would do anything to pay their mortgage-forgo a new car or a vacation, even put a younger family member to work."); 60 Minutes: The U.S. Mortgage 
away from their homes don't understand the value of good credit. ${ }^{13}$

As their personal accounts attest, homeowners who strategically default frequently have excellent credit scores and default despite very clear understandings that defaulting will significantly damage those scores. ${ }^{14}$ Indeed, strategic defaulters often include their predefault credit scores in their personal accounts-apparently to signal that their newly damaged credit scores are not signs of general irresponsibility, as did this incipient defaulter:

"What sets us apart from many is that we have always been fiscally responsible. We don't live beyond our means, we carry no credit card debt. ... Credit rating $>800$. There isn't a lender out there who wouldn't give us a loan."15

Studies have found that in contrast to individuals with good credit scores, low-income homeowners with poor credit scores are less likely to strategically default ${ }^{16}$ - despite the fact that they might have the least to lose in terms of damage to their credit scores and the lowest risk of deficiency judgments by letting go. ${ }^{17}$ One possible explanation for this could

Meltdown (CBS television broadcast May 25, 2008) (with interviewee complaining that "there was a time when I think people felt really bad about not paying off a debt").

13. See, e.g., Nightline: The Big Cut (ABC television broadcast Jan. 31, 2008) (lamenting the failure of homeowners to understand that walking away is a "huge black mark on your credit rating").

14. See E-mail to author (Jan. 13, 2010, 10:41 MST) (on file with the SMU Law Review); see also E-mail to author (Dec. 8, 2009, 15:57 MST) (on file with the SMU Law Review) ("I'm the prime, perfect example of who should be helped, I've never missed any payments in my historical credit life span (I'm 30) and my score is 750 middle fico. That said, where has it gotten me? I'd rather have hundreds of thousands of $\$$ than a high credit score."); E-mail to author (Jan. 31, 2010, 14:07 MST) (on file with the SMU Law Review) ("My quality of life was far more important to me than my stellar 795 credit score."); Email to author (Nov. 18, 2009, 10:21 MST) (on file with the SMU Law Review) ("My credit score was around 730 when I made my last payment and am interested to see what will happen. Of course the mortgage company is trying every threat/tactic they can to keep me in the house and making payments. To no avail.").

15. E-mail to author (Jan. 8, 2010, 10:25 MST) (on file with the SMU Law Review); see also E-mail to author (Jan. 16, 2010, 15:21 MST) (on file with the SMU Law Review) ("We are in our fifties, married for 30 years, European roots, strong moral values and a fiscally conservative.... As a point of reference, our FICO credit score during our entire marriage hovered around the 800+ level and life was great!"); E-mail to author (Feb. 5, 2010, 08:38 MST) (on file with the SMU Law Review) ("[B]oth of our FICO credit scores were high (mine being 840)."); E-mail to author (Dec. 3, 2009, 02:24 MST) (on file with the SMU Law Review) ("Now I have a score of 650 to 700 depending which bureau. My fiance is 28 with a score of over 720."); E-mail to author (Nov. 30, 2009, 12:50 MST) (on file with the SMU Law Review) ("She bought her home within her financial means, has no credit card debt and has always played by the rules."); E-mail to author (Dec. 2, 2009, 23:16 MST) (on file with the SMU Law Review) ("[M]y situation: ... bought new house ... for 325K ... house is work 125-150K . . credit score is upper 700s ... husband is not on house loan ... husband laid off."); E-mail to author (Feb. 18, 2010, 17:09 MST) (on file with the SMU Law Review) ("As an underwater homeowner ... who bought in 2004 at $\$ 755 \mathrm{k}$ with the standard $10 \%$ down and a 800 credit rating, my house today is worth about $\$ 525 \mathrm{k}$.").

16. See Bhutta, Dokko \& Shan, supra note 8, at 26 ("[B]orrowers with the lowest FICO scores (below 620) are not the most 'ruthless.'").

17. See id. ("[A] high-FICO borrower will see a steeper increase in his borrowing cost after a default than a low-FICO borrower.... [G]enerally speaking, borrowers with higher FICO scores find it more costly to default. ... This difference may also reflect the differ- 
be that such individuals treat mortgage payments differently than other financial obligations. ${ }^{18}$ At least some homeowners' accounts support this explanation: "I have a lot of debts and my credit score is probably in 300 's, however I never failed to pay my house payments. I lost my job 2 years ago and i cashed my $401 \mathrm{~K}$, used up all my savings so I can keep up with the payments." 19

A more likely reason for the apparent discrepancy in strategic-default levels, however, is that defaults by low-income individuals with poorcredit scores are rarely classified as strategic, even when they might be. While the line between strategic default and nonstrategic default is hazy, this article defines strategic default as any default where the homeowner could come up with money to pay the mortgage, even if at some significant sacrifice, but chooses not to do so. The Experian credit-reporting agency defines strategic default, however, as when homeowners go straight from current to 180 days late on their mortgages, "while staying current on all their non-real estate debt obligations, 6 months after they first went 60 [days late] on their mortgage." 20 They also specifically exclude financially distressed individuals, ${ }^{21}$ who by nature of their circumstances are likely to have low-credit scores.

But even distressed individuals may be making intentional decisions to stop paying their mortgages while still trying, when possible, to pay off other debts or to spare their savings accounts. ${ }^{22}$ This article, thus, uses a broader definition of strategic default, which includes any deliberate choice to stop paying one's mortgage. A nonstrategic default, by contrast, would be one in which the homeowner simply doesn't have the assets, income, or credit available to pay their mortgage, no matter the sacrifice.

Whatever strategic default's definition, homeowners almost never default at less than $10 \%$ negative equity absent a severe loss of income, ${ }^{23}$ but " $[t]$ he percentage of households willing to default strategically increases to $5 \%$ if the shortfall is between 10 and $20 \%$ of the value of the

ence in the commitment a borrower has to the repayment of debt, which is, to some extent, captured by his FICO score.").

18. See Experian-Oliver Wyman, supra note 1, at 16 (finding that financially distressed borrowers are more likely to fall behind on other accounts before falling behind on the mortgage).

19. E-mail to author (Jan. 14, 2010, 17:36 MST) (on file with the SMU Law Review).

20. See Experian-Oliver Wyman, supra note 1 , at 8.

21. Id.; see also Brent T. White \& Luigi Zingales, Is Strategic Default a Menace?, CITY J. (Apr. 27, 2010), http://www.city-journal.org/2010/forum0427.html (Zingales defining "strategic default" as only when a homeowner could easily afford to make payment and defining any other default as "standard default").

22. For support for this possibility, see Cohen-Cole \& Morse, supra note 8, at 5 (finding that $74 \%$ of households who became delinquent on their mortgage were current on their credit cards).

23. Bhutta, Dokko \& Shan, supra note 8 , at 3, 21 (finding that strategic default is a non-issue at less than $10 \%$ negative equity); Guiso, Sapienza \& Zingales, supra note 8 , at 5 (finding that no borrower reported that they would default at less than $10 \%$ negative equity). 
house and reaches $17 \%$ when the shortfall reaches $50 \% . " 24$ Indeed, at $50 \%$ negative equity, half of all defaults are strategic. 25 One would, of course, logically expect that the propensity to default would increase along with negative equity. But studies showing negative equity's importance in the default decision have shattered long-held beliefs that homeowners will not default as long as they can afford their mortgage payments. ${ }^{26}$

In addition, homeowners who are personally acquainted with someone who has strategically defaulted are much more likely to default than those who are not. ${ }^{27}$ Finally, and unsurprisingly, homeowners who don't think it's immoral to default are significantly more likely to default than those who do. ${ }^{28}$ Importantly, however, even individuals who don't think default is immoral are still much less likely to strategically default than to pay their mortgages, even with $\$ 100,000$ in negative equity. ${ }^{29}$ Indeed, the evidence remains strong that most homeowners-whether they believe they have moral obligation to pay or not-don't strategically default even with very significant negative equity. ${ }^{30}$

Despite this fact, there has been a recent increase in the percentage of defaults that are apparently "strategic," and there is some indication that this trend is likely to continue. ${ }^{31}$ To the extent that policymakers or lenders would like to temper this trend, it would be helpful to know more about strategic defaulters' decision-making processes. Other than some broad demographic generalities, however, we know little about strategic defaulters, and no study to date has looked at their decision-making processes.

Part of the reason for the lack of such a study is that, due to the social stigma involved, people rarely openly identify themselves as strategic de-

24. Guiso, Sapienza \& Zingales, supra note 8, at 5 .

25. Bhutta, Dokko \& Shan, supra note 8 , at 3 .

26. Guiso, Sapienza \& Zingales, supra note 8 , at 21.

27. $I d$. at 22 .

28. Id. at $21-22$.

29. Id. at 10 (finding that $59 \%$ of individuals who don't think default is morally wrong would strategically default at $\$ 200,000$ in negative equity and $41 \%$ would default at $\$ 100,000)$.

30. See Neil Bhutta, Jane Dokko \& Hui Shan, How Low Will You Go? The Depth of Negative Equity and Mortgage Default Decisions 1 (Fed. Reserve Bd. of Governors, Preliminary Working Paper 2010) (finding "that many homeowners require considerable negative equity before defaulting, with $\$ 138,000$ being the median negative equity among strategic defaulters").

31. See, e.g., 2010 Predictions from Shiller, Blinder, Rajan and More, supra note 1 (quoting Robert Shiller as predicting in 2010 that "[s]trategic default on mortgages will grow substantially over the next year, among prime borrowers, and become identified as a serious problem. The sense that 'everyone is doing it' is already growing, and will continue to grow, to the detriment of mortgage holders."); Sapienza \& Zingales, supra note 1 (finding a sharp increase in strategic default from $22 \%$ of foreclosures to $31 \%$ in just one year); Monica Hatcher, Homeowners Walking Away from Underwater Mortgages, MiAmi Her. ALD, Oct. 24, 2009, available at 2009 WLNR 21149054 (Westlaw NewsRoom); EXPERIANOLIVER WYMAN, supra note 1 , at 10 (finding that the percentage of defaults that are strategic increased from $3 \%$ in the fourth quarter of 2004 to $18 \%$ in the fourth quarter of 2008); Streitfeld, supra note 1 (discussing this trend). 
faulters and frequently try to hide the fact that they strategically defaulted by proffering more socially acceptable explanations for losing their homes to foreclosure. ${ }^{32}$ By consequence of having written a widely publicized article on the emotional constraints to default, ${ }^{33}$ however, I have received over 350 personal accounts from homeowners who, by their own admissions, have either already strategically defaulted on their mortgages or are considering doing so. These narratives frequently go into great detail about the circumstances and the processes that led the homeowners to decide to stop paying their mortgages.

This article is based upon these narratives, which were categorized and coded according to the factual circumstances leading to the default decision and the emotions accompanying it. This sorting revealed a picture of the incipient strategic defaulter as deeply underwater, terribly anxious, hopeless, and frequently angry - subject, of course, to individual variation in intensity and sequence. This picture stands in contrast to the popular image of strategic defaulters as greedy, dismissive of the consequences of their actions to others, calculating, and cold. This is not to say that there are not strategic defaulters out there who fit this popular caricature, but they were not represented in the accounts reviewed for this article.

One must be careful of course about drawing conclusions about strategic defaulters in general based upon a self-selected sample, who-like all individuals-would tend to represent themselves in the most sympathetic light. As such, unflattering emotions such as greed, envy, and vengefulness are likely to be underrepresented and hidden in these accounts. There are also possible selection bias issues because the people who wrote may or may not be completely representative of strategic defaulters in general. ${ }^{34}$

32. Guiso, Sapienza \& Zingales, supra note 8, at 4. Another possible reason that no one has studied the emotions associated with strategic default is that economists and other researchers interested in strategic default have not seen the emotional process of default as important enough to study. In fact, "[m]ost mortgage default risk modeling . . does not account for the primacy of emotion in driving human behavior and decision-making." White, supra note 6, at 18 (explaining that emotion "may not matter if the goal is to merely describe or model observable human behavior, but it does matter to the extent that policymakers and others are interested in encouraging individuals to make different choices-or to continue to make the same choices for that matter").

33. See generally White, supra note 6.

34. My sense, informed by numerous conversations over time with professionals who work with homeowners considering strategic default, is that these accounts are in fact quite representative. I could be wrong, however. The sample may, for example, be more educated (e.g., they heard about my previous work), more sophisticated, and perhaps wealthier. E-mail to author (May 10, 2010, 16:10 MST) (on file with the SMU Law Review). They may also be less likely to be ashamed of strategically defaulting (or, conversely, they may feel more shame and thus wrote seeking to be validated by someone seemingly sympathetic to their plight). Id. The sample may also be more or less anxious and angry than the average defaulter. Given their sophistication, they might also be prone to make more informed decisions than the average person. Or, as my informed gut tells me, they might be pretty typical of strategic defaulters as a class. Without further quantitative study, it's impossible to know for sure. Regardless, it is unlikely that walking away from one's home is an unemotional event for very many people. Even if there are homeowners who are making purely rational economic decisions to walk away, we should not ignore those homeowners for whom the decision is a lot more complicated and a lot more emotional. 
Nevertheless, the accounts of these 356 homeowners offer a useful window into the decision-making processes - and personal justifications-of at least some underwater homeowners who strategically default. Additionally, while filling in many gaps and adding emotional texture, these accounts are largely consistent with recent quantitative studies on strategic default. The accounts' consistency with the quantitative research on strategic default gives comfort that they are not unrepresentative-as does their significant number.

Moreover, the chief limitation of these accounts is also their strength because homeowners sent their stories without invitation, they were not guided by survey questions, influenced by an interviewer's cues, nor even aware in advance that their accounts would become part of a greater project related to understanding strategic default's emotional drivers. ${ }^{35}$ This article is based upon homeowners speaking freely in their own voice-a voice to which policymakers and the mortgage industry might do well to listen. ${ }^{36}$

\section{A PRELUDE: NOT SHAMELESS}

Before turning to the emotions that drive strategic default, it's important to address one popular misconception about the cause of the apparent trend toward increasing strategic default: namely, that the social and moral constraints against defaulting on one's mortgage have begun to give way, and thus, people no longer feel guilt or shame when defaulting. ${ }^{37}$

As an initial matter, the suggestion that the social norm against defaulting on one's mortgage has weakened is belied by surveys showing that it remains strong and, if anything, may be getting stronger. A study by Guiso, Sapienza, and Zingales found in 2009 that eighty-one percent of

35. The accounts and quotes contained in this article have been modified only to the extent necessary to protect the identities of those who shared their stories. To that end, typographical and grammatical errors have been left as is, but the names of the individuals have been omitted and initials in the citations are not actual initials. In addition, names of cities have sometimes been changed to similar cities or omitted altogether. Dates have also been changed but in a manner that preserves time periods (as in the number of days, months, or years involved). The names of lenders, however, have been left as contained in the stories of the homeowners. The accounts of homeowners have not been verified and are presented here not as statements of factual truth, but for their emotional content and what they reveal about the decision-making process of strategic defaulters. They are intended to be read as such.

36. For an excellent, and classic, exploration of the importance of stories and the methodological validity of narrative scholarship, see Kathryn Abrams, Hearing the Call of Stories, 79 CAL. L. REv. 971 (1991) and Kathryn Abrams, Introduction: The Paths of Stories, 76 UMKC L. Rev. 789 (2008).

37. See Suzanne Kapner, Setback for US Mortgage Sector, Fin. TImEs, Apr. 30, 2010, at 6 (London) (paraphrasing Jon Maddux, the chief executive of You Walk Away, that "the moral stigma attached to walking away [has] started to dissipate" and quoting him saying, "People are starting to change their way of thinking. It's almost become trendy to walk away from your home."); see also Guiso, Sapienza \& Zingales, supra note 8, at 22 (expressing concern that "the social pressure not to default is weakened when homeowners live in areas with high frequency of foreclosures or know other people who defaulted strategically"). 
Americans believed that it was morally wrong to default on one's mortgage. ${ }^{38} \mathrm{~A}$ similar study by Fannie Mae in 2010 found that eighty-eight percent of Americans believed that it was morally wrong to default, and eighty-five percent believed it was morally wrong even if one faced financial difficulties such as unemployment that made it difficult to pay one's mortgage. ${ }^{39}$ The stigma against default apparently remains robust; indeed, homeowners who strategically default sometimes report being shunned by others: "I am ... retired . . . and I was forced to walk away from my home and an investment condo .... My husband and I . . were shunned in our condo development. In essence, my neighbors are blaming me for a global real estate meltdown." 40

More critically, however, the Fannie Mae survey found that seven out of ten individuals who defaulted on their own mortgages did not believe it was acceptable for people to stop making payments on an underwater mortgage. ${ }^{41}$ The Fannie Mae survey does not distinguish, however, between strategic defaults and nonstrategic defaults-and no survey has ever been conducted of strategic defaulters in particular to determine the level of shame or guilt that they actually feel about their decisions.

Even if an empirical study were conducted, however, there would be no baseline for comparison. Do people strategically default because they feel less guilt and shame about defaulting than they would have at some earlier point in time, or are those who strategically default just individuals who never thought it was immoral or shameful to default in the first place? The only way to know this for sure would have been to survey a group of homeowners at the housing crisis's start about their attitudes toward default, monitor them over time to see if any of them defaulted, and then survey them again. It's too late for that now.

Actual strategic defaulters' accounts suggest, however, that at least some people who strategically default do so despite very strong feelings of guilt and shame:

I am a single mother and have been saddled with a home that I just can't afford. It's been taking almost all of my paycheck to cover the 1st and 2cd mortgages- having to use the credit card to cover all other expenses. I have done everything to hold on to avoid the shame of foreclosure. I have racked up over twenty thousand dollars in debt trying to keep things a float, hoping I could eventually sell the home and pay off my credit debt-and break even. What a foolish thing for me to do. The house is appraising less and less ever year-

38. Guiso, Sapienza \& Zingales, supra note 8 , at 21.

39. See Press Release, Fannie Mae, New Nationwide Survey Provides Comprehensive Look at Sentiment Toward Housing (Apr. 6, 2010), http://www.fanniemae.com/newsreleases/2010/4989.jhtml?p=Media\&s=News+Releases.

40. E-mail to author (Feb. 1, 2010, 12:04 MST) (on file with the SMU Law Review); see also E-mail to author (Nov. 5, 2009, 11:53 MST) (on file with the SMU Law Review) ("I am tired of talking to people (sometimes friends, sometimes strangers) who view me as being immoral due to my decisions. They can't grasp the fact that the lenders have to share the blame and the risk.").

41. See Press Release, Fannie Mae, supra note 39. 
and nothing is moving in the neighborhood. I was advised to allow the house to go into foreclosure - which I have reluctantly began to do (I have never missed or been late on any payment ever). ${ }^{42}$

In other words, as the Fannie Mae survey suggests, many people may strategically default not because they're shameless but because circumstances overwhelm their shame, driving them to make decisions that they would not have made otherwise: "We are not proud of our circumstances. We always had excellent credit and have honored our financial obligations on all of our other homes, cars and credit card companies. But this is what we must do, as scary as it is."43

Of course, this doesn't mean that the social stigma against default hasn't weakened in some neighborhoods. There does seem to be a contagion effect: once one home in a neighborhood goes into foreclosure, others tend to follow. ${ }^{44}$ This is likely true in part because it's less embarrassing-and less frightening-to be the second or third person in the neighborhood to be foreclosed upon than the first. Additionally, people are much more likely to default strategically if they know someone else

42. E-mail to author (Dec. 1, 2009, 07:59 MST) (on file with the SMU Law Review); see also E-mail to author (Dec. 20, 2009, 14:42 MST) (on file with the SMU Law Review) ("This has been especially hard since I am a commissioned officer, and guilt, fear, and duty weigh heavily on my mind ...."); E-mail to author (Apr. 30, 2010,11:06 MST) (on file with the SMU Law Review) ("It is a common argument, (a manager at my local bank "tossed" this line of thinking my way) that when people default in this manner, they are doing their fellow citizens an extreme disservice making it harder on those who are applying for and paying on other for loans, because the bank is at a disadvantage due to the non-pay of their patrons. Though, in my mind and heart, my main desire and goal is to do what's best for my family, this type of argument causes me to reel in the shame of causing/creating a negative situation for my fellow community members."); E-mail to author (Apr. 30, 2010, 10:26 MST) (on file with the SMU Law Review) ("we did not default without numerous conversations, discussions, and soul searching beyond belief. The hardest part to justify is the loss we may have caused our neighbors. They weren't paying our bills though."); Email to author (Dec. 11, 2009, 09:15 MST) (on file with the SMU Law Review) ("I walked. ... I know there are a lot of people struggling with internal conflict, integrity and the socially acceptable thing to do. ... It can be a very lonely, isolating and psychologically challenging process . . . a need for sharing is now as so many are suffering in silence."); Email to author (Jan. 31, 2010, 10:05 MST) (on file with the SMU Law Review) ("I fit the bill of feeling it wouldn't be the right thing to do, but do feel a responsibility to pay. ... I have contacted Wells Fargo Home mortgage for getting my principal lowered so I can make payments and keep my home. Of course they have been giving me the run around for months. I am seriously thinking of walking."); E-mail to author (Feb. 1, 2010, 18:35 MST) (on file with the SMU Law Review) ("My husband and I . . . want to look at this situation from a business perspective, my question for you is how does one determine if you should walk away? ... Any thoughts would be greatly appreciated as we wrestle with our consciousess.") For a detailed discussion of the role of shame and guilt in constraining strategic default, see White, supra note 6.

43. E-mail to author (Nov. 30, 2009, 12:03 MST) (on file with the SMU Law Review).

44. See Guiso, Sapienza \& Zingales, supra note 8, at 20; John P. Harding, Eric Rosenblatt \& Vincent W. Yao, The Contagion Effect of Foreclosed Properties, 164 J. OF URBAN ECON. 164, 169 (2008); E-mail to author (Feb. 2, 2010, 12:55 MST) (on file with the SMU Law Review) (nicely illustrating this phenomenon: "Many of my great neighbors ... [made] the smart financial decision to leave. I may too. We bought for $\$ 383 \mathrm{~K}$ and Zillow.com estimates our home value at $\$ 176 \mathrm{~K}$. Our lender-Wells Fargo is dragging its feet. My next door neighbor is short selling. They lost $60 \%$ of their income and Well Fargo's modification offer was only $\$ 100$ less per month!"). 
who has done so. ${ }^{45}$ As strategic defaulters' personal accounts seem to confirm, once one individual within a close-social circle defaults, others within the circle sometimes follow:

Most of my friends are in similar situations as myself-we all bought in our late 20's, at the height of the boom. Since then, we have done nothing but bitch about how much inequity we have in our houses. . . . Some have started to not make payments; others are playing "wait and see" with my situation. I have no doubt I will come out on top and they will be encouraged to do the same. ${ }^{46}$

But the existence of a contagion effect doesn't mean that strategic default has become more socially acceptable in general. Nor does it mean that strategically defaulting has lost its stigma to those who do it. Indeed, even strategic defaulters who are comfortable disclosing their defaults to similarly situated neighbors or friends are generally not comfortable doing so outside of these small circles. As one strategic defaulter explained:

I have only told two friends about this. It is going to be difficult to tell other friends and our neighbors. Fortunately, my parents live in the mid-west and at sometime this year I will simply write to them and tell them that we are selling our house. I think they would be completely opposed to this. ${ }^{47}$

In other words, it doesn't seem that the increase in strategic default is the result of a large-scale change in social norms or shamelessness among individual strategic defaulters.

Indeed, even the contagion effect seems to be less about changing social norms than about decreased property values caused by other foreclosures. ${ }^{48} \mathrm{~A}$ foreclosure in a neighborhood can reduce the value of other homes in the neighborhood. ${ }^{49}$ As property values decrease, people who were already underwater on their mortgages become moreso, pushing some over their individual tipping point. This leads to still more foreclosures and further declines in property values, pushing still more people over their tipping point:

Nearly all my neighbors bought at the height of the real estate boom and paid as much as $100 \mathrm{~K}$ more than I. Most are moving out and allowing the banks to foreclose. As I watch this I have become con-

45. Guiso, Sapienza \& Zingales, supra note 8, at 6 ("[P]eople who know someone who defaulted strategically are $82 \%$ more likely to declare their intention to do so.").

46. E-mail to author (Feb. 2, 2010, 09:12 MST) (on file with the SMU Law Review).

47. E-mail to author (Jan. 19, 2010, 10:00 MST) (on file with the SMU Law Review); see also E-mail to author (Dec. 21, 2010, 07:07 MST) (on file with the SMU Law Review) ("Also, while I am not ashamed about our decision, the converse of not being ashamed does not equal being proud of it."); E-mail to author (Jan. 16, 2010, 15:21 MST) (on file with the SMU Law Review) ("I am sensitive to the unfair media biases and societal humiliations that exist ....").

48. See, e.g., Bhutta, Dokko \& Shan, supra note 8, at 23-24; Bajari, Chu \& Park, supra note 8 , at 21 .

49. See Harding, Rosenblatt \& Yao, supra note 44, at 174 ("[N]earby distressed property has a significant, negative effect on the prices of nearby homes over and above the overall trend in market prices."). 
cerned as well. ... I I am current but no longer willing to keep on paying for a house in a declining market. If my neighborhood weren't as empty I may have been willing to keep paying the mortgage. ${ }^{50}$

\section{ANXIETY AND FEAR}

Recent quantitative studies well-documented the role of decreasing property values and negative equity in driving strategic default.51 But homeowner accounts suggest that decreasing property values and negative equity alone may not cause strategic default. Rather, they evoke emotions-namely, financial anxiety and distress-and these emotions, when strong enough, can lead some homeowners to begin to contemplate strategic default. But strategic default might never cross the minds of other equally underwater homeowners who, for whatever reason, feel less anxious about their situations.

To understand anxiety's particular role in strategic defaulters' decisionmaking processes, it's first necessary to understand the defaulters' circumstances. Initially, the average strategic defaulter is deeply underwater on their mortgage-usually over $\$ 100,000$ and frequently much more. 52

50. E-mail to author (April 25, 2010, 04:31 MST) (on file with the SMU Law Review); see also E-mail to author (Jan. 8, 2010, 10:25 MST) (on file with the SMU Law Review) ("[O]ur neighborhood has suffered from multiple foreclosures which has driven prices down even lower. By our calculations, we will not live long enough to recoup our losses so its time to get out of Dodge and once we pull the trigger we will not look back."); E-mail to author (Feb. 2, 2010, 09:41 MST) (on file with the SMU Law Review) ("[T]hey didn't want to be the last ones left on block with a huge mortgage.").

51. See, e.g., Bhutta, Dokko \& Shan, supra note 8, at 1, 3 (finding that $50 \%$ of defaults are strategic once negative equity reaches $50 \%$ ); Bajari, Chu \& Park, supra note 8 , at 5 (finding that a default probability increases by $15 \%$ with a $20 \%$ decline in house prices).

52. See Bhutta, Dokko \& Shan, supra note 8, at 7 (finding that the median strategic defaulter is $62 \%$ or $\$ 138,000$ underwater); see also E-mail to author (Jan. 6, 2010, 11:57 MST) (on file with the SMU Law Review) ("I . . have a nasty loan from Countrywide and now find myself owing $\$ 320,000$ more then what the house is currently worth."); E-mail to author (Nov. 30, 2009, 13:56 MST) (on file with the SMU Law Review) ("However, what do you do when you have $\$ 50,000$ sunk into a previously $\$ 250,000$ home that is now about $\$ 130$.....); E-mail to author (Jan. 27, 2010, 11:26 MST) (on file with the SMU Law Review) ("Our house has lost more then $50 \%$ of its value, based on reasonable estimates."); E-mail to author (Jan. 31, 2010, 09:31 MST) (on file with the SMU Law Review) ("[M]y wife and $i$ are a senior age couple with a home . . . in which we have $\$ 262,000$ invested with a current value of \$115000-135000."); E-mail to author (Nov. 30, 2009, 23:05 MST) (on file with the SMU Law Review) ("My wife and I purchased a home in [], formerly the fastest growing town in America, in 2006 for $\$ 520,000$. We put nearly $\$ 100,000$ down. We attempted a short sale and the appraised price, which is unreasonably high, came in at $\$ 270,000$. We currently owe nearly $\$ 490,000 \ldots$. . "); E-mail to author (Feb. 18, 2010, 17:09 MST) (on file with the SMU Law Review) ("As an underwater homeowner ... who bought in 2004 at $\$ 755 \mathrm{k}$ with the standard $10 \%$ down and a 800 credit rating, my house today is worth about $\$ 525 \mathrm{k}$."). These stories are consistent with what we know about price declines in the hardest hit markets. For example, the median sale price of a Las Vegas home was approximately $\$ 280,000$ in 2006 and $\$ 130,000$ in early 2010 . Las Vegas Home Prices and Home Values, Zillow, http://www.zillow.com/local-info/NV-Las-Vegashome-value/r_18959 (last visited Oct. 30, 2010). In Phoenix, the median sale price was $\$ 245,000$ in late 2007 and $\$ 125,000$ in early 2010. Phoenix Home Prices and Home Values, 
Homeowners who are so underwater might be expected to worry about recovering their lost equity. Strategic defaulters, however, seem to be especially pessimistic, lacking many homeowners' confidence that housing prices will recover in the near future,$^{53}$ as the following anecdote illustrates: "[I] own three houses, two of which (one 80\%) [are] underwater. The problem is I'm just running out of money and simply see no rebound, anytime in the next 5-7 years." 54

In addition to being pessimistic about a housing recovery, the strategic defaulters who shared their stories were not so wealthy that walking away from their mortgage was a mere financial exigency. ${ }^{55}$ Again, this doesn't mean that there aren't individuals out there who strategically default

ZILLOw, http://www.zillow.com/local-info/AZ-Phoenix-home-value/r_40326 (last visited Oct. 30, 2010). And, in Salinas, Cal., the median sale price peaked at over $\$ 600,000$ in 2006 but stood at just $\$ 225,000$ in early 2010. Salinas Home Prices and Home Values, ZiLLow, http://www.zillow.com/local-info/CA-Salinas-home-value/r_54288 (last visited Oct. 30, 2010).

53. Most homeowners tend to be optimistically overconfident about both the actual value of their homes and chances that home prices will bounce back in a few years. See Peter Ubel, Human Nature and the Financial Crisis, Forbes (Feb. 22, 2009, 12:01 AM), http://www.forbes.com/2009/02/20/behavioral-economics-mortgage-opinions-contribu-

tors_financial_crisis.html (discussing the human susceptibility to "unrealistic optimism"); Chris Dillow, Housing Over-Confidence, Investors Chron. (Apr. 27, 2009), http://www. investorschronicle.co.uk/MarketsAndSectors/Markets/article/20090427/52772fa2-331a-11 de-8f90-00144f2af8e8/Housing-overconfidence.jsp (discussing the fact that homeowners tend to underestimate price declines: "If your biggest exposure to housing market economics came when you bought during a boom-and of course, many more people buy in booms than slumps-rapid house price appreciation will loom large in your mind. This will cause you to over-estimate its size and frequency, and so over-estimate your own house price."); Lauren Ross, The Internal Costs of Foreclosure: A Qualitative Study Exploring Issues of Trust, Insecurity, and Self in the Face of Foreclosure 38 (Aug. 31, 2009) (unpublished M.A. thesis, University of Delaware) (on file with author) ("Many individuals are reluctant to acknowledge that the housing and mortgage markets have significantly changed and are no longer wholly sustainable or lucrative investments.").

54. E-mail to author (Nov. 29, 2009, 18:58 MST) (on file with the SMU Law Review); see also E-mail to author (Feb. 4, 2010, 12:55 MST) (on file with the SMU Law Review) ("If and only if, the market came back and earned an average of $2.5 \%$ per year, it would take me about 10.3 years just to break even! Not only that, during that time, I'm going to spend over $106 \mathrm{~K}$ in mortgage payments to recoup my $70 \mathrm{~K}$ deficit."); E-mail to author (Feb. 9, 2010, 09:50 MST) (on file with the SMU Law Review) ("My wife feels we can regain our lost equity in time, but I truly believe it won't happen fast enough to save our home.").

55. Indeed, the strategic defaulters who shared their stories seem to be predominantly members of the middle class. See, e.g., E-mail to author (Apr. 25, 2010, 06:10 MST) (on file with the SMU Law Review) ("My wife and I are both teachers-in other words, we don't make a ton of money but are happy with our jobs. But, we feel like we are being taken for a ride."); E-mail to author (Jan. 18, 2010, 19:50 MST) (on file with the SMU Law Review) ("We own part of a home ... that our son lived in until he relocated to another state, and since then have tried to rent the house, but we cannot rent the home for anywhere near enough to make the payment, so each month we are paying money out that we could use to help live on. We are both retired public school teachers ... and the money we are paying out could be used by us."); E-mail to author (Jan. 21, 2010, 12:29 MST) (on file with the SMU Law Review) ("I am considering my options (am $\$ 100 \mathrm{k}$ underwater in a house I paid $\$ 300 \mathrm{k}$ for in December, 2006) .... I have decent income, plenty to cover my mortgage, but due to other debts live paycheck to paycheck and have no savings or assets to speak of."); E-mail to author (Mar. 8, 2010, 17:21 MST) (on file with the SMU Law Review) ("Here's my situation.... I owe approx. $\$ 600,000$ to my mortgage, second mortgage and credit card. My condo . . . is worth approx. $\$ 500,000$. I'm struggling right now to meet my monthly minimums for all my bills and am faced with a ballooning mortgage in a couple of months 
purely out of greed. But many homeowners who strategically default must make a choice between paying for their mortgage and satisfying some other real or perceived financial imperative. In other words, they could pay their mortgage but only at some significant cost.

For underwater homeowners who have lost their jobs, paying the mortgage frequently means cleaning out their bank accounts and using up their savings. Indeed, many homeowners who eventually choose strategic default don't seem to even consider it until they have greatly depleted or exhausted their reserves:

My husband and I were laid off ... almost a year ago now. We are up to date on our mortgage payments and bills but our savings are now gone along with most of our retirement-account-that we cashed in to keep afloat. We are upside down on our home and have a second mortgage so selling it isn't an option. I looked into a Short Sale but I don't think we can keep up with the payments for the months it would take for that to go through .... if it would at all. We are considering just walking away from our home or filing bankruptcy. ${ }^{56}$

Others begin to consider strategic default only once paying the mortgage threatens their retirement security or their very ability to retire at all. These individuals, like many homeowners, typically bought their homes as part of their investment strategy for retirement: "We bought our house with the expectation that it would be a fair investment and we could at least break even in about 10 years when we retire. At this point, we won't be able to retire until our late 80s." 57

and am looking for a solution. While I don't feel $100 \%$ comfortable walking away from my debt I do feel that it's in my best interest.").

56. E-mail to author (Dec. 5, 2009, 09:21 MST) (on file with the SMU Law Review); see also E-mail to author (Feb. 1, 2010, 18:35 MST) (on file with the SMU Law Review) ("My husband and I are in the precarious position of being current with our mortgage but our income has dropped over $40 \%$ and the house value has also dropped $20-30$ percent and we cannot get our interest only loan modification out of its temporary status. We have sacrificed for months, our savings is gone, our credit is jeopardized."); E-mail to author (Dec. 3, 2009, 08:51 MST) (on file with the SMU Law Review) ("We have never missed a payment, but in turn we depleted our savings and other equity $\$ \$$ we had in our primary home."); E-mail to author (Jan. 14, 2010, 17:36 MST) (on file with the SMU Law Review) ("I lost my job 2 years ago and i cashed my $401 \mathrm{~K}$, used up all my savings so I can keep up with the payments."); E-mail to author (Nov. 29, 2009, 15:30 MST) (on file with the SMU Law Review) ("My wife and I have recently retired from public school teaching, and during this time I became disabled. We have been rapidly spending every dollar we have trying to stay in our house, but the time has come for us to walk, as our savings and one annuity are depleted. The current market value of our house is about $\$ 150,000$ under our mortgages. ... Our mortgage payment is set to almost double next summer, and we have worked arduously to get something workable in advance of that avalanche.").

57. E-mail to author (Jan. 19, 2010, 10:00 MST) (on file with the SMU Law Review). Indeed, concerns about retirement were on the minds of a significant majority of strategic defaulters who shared their stories. See, e.g., E-mail to author (Dec. 10, 2009, 12:29 MST) (on file with the SMU Law Review) ("We struggle over what to do, at 50 years old we can't continue to throw away what little money we have on this house."); E-mail to author (Jan. $6,2010,11: 57$ MST) (on file with the SMU Law Review) ("I . . . have a nasty loan from Countrywide and now find myself owing $\$ 320,000$ more then what the house is currently worth. We are in our late forties-finally got a loan mod from Countrywide, we can keep the house if we pay on an interest-only until we are 80."); E-mail to author (Mar. 2, 2010, 14:09 MST) (on file with the SMU Law Review) ("My wife and I own 2 homes. One a 
For still others, continuing to pay mortgage creates tensions with the countervailing obligation to provide for their children's future, including paying for college: "Not to mention that I have two daughters in college whose education we are funding mainly with loans because we have not been able to save or have any extra funds to assist them in obtaining an education." 58

The most financially stretched, however, are frequently faced with the choice of defaulting on their mortgages or having to use credit cards to stay afloat and to purchase basic necessities such as food and clothing:

We have drained out savings paying the mortgage because of the fear of being late. I just made Novembers payment on the 30th and don't know how we're going to pay December. Our mortgage servicer offers no extensions. We've spent everything we have to keep our credit intact. We now have a kids bedroom stopped in the middle of a remodel, a gaping hole in the kitchen from a major leak and no money to finish or fix either of them. We do have a Discover card with a $\$ 9,000$ limit and no balance but really . . . don't want to put ourselves in more of a hole. We could use the blank checks from it to pay the mortgage and hope I find the job I deserve and have the funds to pay it back, but I know it's unwise to pay for an interest bearing debt with funds from another. At which point in time does it become OK [to stop paying the mortgage]? It sounds so beneficial to save a couple hundred dollars a month right now, that's money for food, gas, clothing and so on. ${ }^{59}$

Faced with such difficult choices, homeowners considering strategic de-

primary residence and the other a personal vacation property. Both homes were refinanced three years ago with a 5 year interest only arm. However, two years ago, I needed to take early retirement as a Middle School Principal due to health concerns. . . . As the early retirement came unexpectedly, the carrying of the second mortgage is now dipping into retirement accounts each month. The house is has been on the market for the past year, however, it is not looking good at this point."); E-mail to author (Feb. 16, 2010, 12:55 MST) (on file with the SMU Law Review) ("I am a successful professional ... who has always maintained great credit. But I currently own nine rental properties that are regularly vacant or need work, upside down and eating away at my retirement portfolio. . . . I'm at a point now where I'm at a loss for what to do.").

58. E-mail to author (Feb. 1, 2010, 15:55 MST) (on file with the SMU Law Review); see also E-mail to author (Dec. 10, 2009, 22:25 MST) (on file with the SMU Law Review) ("With a baby boy on the way, it is our duty to make financially sound decisions in this upcoming year and plan to be very savvy on our future endeavors as well."); E-mail to author (Dec. 3, 2009, 08:51 MST) (on file with the SMU Law Review) (defaulting because "[w]e have two little boys ages 10 and 12" and must think about their futures).

59. E-mail to author (Dec. 3, 2009, 02:42 MST) (on file with the SMU Law Review); see also E-mail to author (Dec. 5, 2009, 13:42 MST) (on file with the SMU Law Review) ("In addition to my mortgages, I graduated law school with around $\$ 70,000$ in student loans, and my wife owed around $\$ 120,000$. We have also utilized $0 \%$ credit cards in an effort to stay afloat after I lost my job, and we currently owe around $\$ 36,000$ on various $0 \%$ credit cards (some of the promotional rates expire in March 2010, two others in May 2010 and one other in July 2010)."). 
fault report feeling "stressed,"60 "agonized,"61 "overwhelmed,"62 and trapped. ${ }^{63}$ They also describe feeling as though they are "fighting a losing battle,"64 "sinking lower and lower,"65 throwing their money down a hole, ${ }^{66}$ and fighting for their lives. ${ }^{67}$ Moreover, the strategic defaulters who shared their stories struggled with these feelings for quite some time before making the decision to stop paying their mortgages. ${ }^{68}$

\section{HOPELESSNESS}

The reason that many strategic defaulters struggle so long before deciding to default is that fear and anxiety are not typically enough in isolation to cause them to stop making payments. Rather, such anxiety more frequently serves as a call to action, driving homeowners to try to do something about their situation, such as contacting their lender to try to work out a loan modification or a short sale. In fact, not a single strategic defaulter in the 356 accounts reviewed for this article reported having stopped paying their mortgage without first contacting their lender. To the contrary, accounts such as these were common:

60. E-mail to author (Dec. 3, 2009, 08:51 MST) (on file with the SMU Law Review) ("The stress level at home is at an all time high.").

61. E-mail to author (Dec. 21, 2009, 07:07 MST) (on file with the SMU Law Review) ("My husband and I had agonized for about a year of what to do with our underwater situation-we pulled the trigger a couple of months ago, and yes, one of the many variables that we had to overcome was the fear of the effect on our great credit and our prospects for future employment.").

62. E-mail to author (Feb. 12, 2010, 16:04 MST) (on file with the SMU Law Review) ("[T]he fear . . . is overwhelming. ... We cannot continue to support two houses (we moved several states away in October 2008).").

63. E-mail to author (Dec. 1, 2009, 08:38 MST) (on file with the SMU Law Review) ("We have excellent credit, can afford our home-technically, but are underwater over $\$ 100 \mathrm{k}$ and really don't like living in the area we live anymore. Our house purchase was only supposed to be for a couple of years but no we have little choice.").

64. E-mail to author (Jan. 23, 2010, 12:35 MST) (on file with the SMU Law Review) ("We bought a home . . . in 2005 for $\$ 886 \mathrm{k}$ with an interest only loan and a home equity line. Comparables in the area are going for about $\$ 650 \mathrm{k}$ or $\$ 700 \mathrm{k}$. We can barely make the payments and have had to relocate for my husband's work and are now renting the house for about $60 \%$ of the mortgage. We wanted to 'do the right thing' and make it work, but it increasingly seems like a waste of money. If it had its original value it wouldn't seem like such a losing battle, but its not.").

65. E-mail to author (Jan. 14, 2010, 10:19 MST) (on file with the SMU Law Review) (describing "the past two plus years of sinking lower and lower in financial standing").

66. E-mail to author (Jan. 18, 2010, 19:50 MST) (on file with the SMU Law Review) ("At this point, we are pouring $\$ 600$ each month down a rat hole, money which we will most likely never get back, and all things considered, walking away sounds pretty good.").

67. E-mail to author (Nov. 29, 2009, 18:58 MST) (on file with the SMU Law Review) ("I'm underwater and must give up my properties, literally to save my life.").

68. See, e.g., E-mail to author (Dec. 21, 2009, 07:07 MST) (on file with the SMU Law Review) ("My husband and I had agonized for about a year of what to do with our underwater situation-we pulled the trigger a couple of months ago ....."); E-mail to author (Apr. 30, 2010, 06:13 MST) (on file with the SMU Law Review) ("Underwater homeowners who obtained their mortgages based on good credit and salary history, including me, have been up against impossible odds, particularly if sudden job loss occurs and it becomes impossible to sell the home in an overinflated market. I arduously tried to sell my home for 10 months after losing my job in 2005 , fixing it up in the process, but finally just walked away in 2006."). 
[T] oward the end of 2008, I began taking a good, hard, long look at my financial situation, and realized I was in trouble. I was in an interest only loan on my 1st [mortgage], and had a 30k balance on my 2nd... . [I]n January, 2009, I began a proactive campaign to get my 1st mortgage modified. ${ }^{69}$

Many underwater homeowners who seek help from their lenders, however, are turned away at the door. ${ }^{70}$ As one homeowner explains, "I called my lender and ask if I could discuss a loan modification and they said absolutely not."71 Lenders give numerous reasons for this, most commonly that homeowners are current on their mortgages. ${ }^{72}$

This is because most lenders don't modify mortgages or agree to short sales for homeowners who might continue making their payments absent

69. E-mail to author (Jan. 31, 2010, 12:24 MST) (on file with the SMU Law Review); see also E-mail to author (Feb. 5, 2010, 08:38 MST) (on file with the SMU Law Review) ("Due to all these events, I approached Wells Fargo and asked about a loan modification for this condo loan in March 2009."); E-mail to author (Dec. 10, 2009, 22:25 MST) (on file with the SMU Law Review) ("Of course we will not be able to pay it off by then and our attempts to be proactive with Wells Fargo and BOA is going awful as they don't want to do anything with us until we start defaulting on our loan. We are upside down by about $50 \%$ (paid $425 \mathrm{k}$ in Dec. 2005 and just got it appraised at $222 \mathrm{k}$ earlier this year and still dropping).").

70. See, e.g., E-mail to author (Dec. 10, 2009, 22:25 MST) (on file with the SMU Law Review) ("[I]t's absolutely amazing that the banks WILL NOT work with us. With a baby boy on the way, it is our duty to make financially sound decisions in this upcoming year and plan to be very savvy on our future endeavors as well."); E-mail to author (Feb. 19, 2010, 09:11 MST) (on file with the SMU Law Review) ("I have two friends who are TRYING to work with their lenders to modify and/or short sale and of the three of us we have all come up empty."); E-mail to author (Nov. 29, 2009, 19:57 MST) (on file with the SMU Law Review) ("My daughter recently lost her job ... and her husband is a [high school] teacher.... They have a two year old daughter. They have contacted Wells Fargo Bank on two occasions pleading for a reduced payment schedule and where flatly told-NO!").

71. E-mail to author (Apr. 26, 2010, 21:09 MST) (on file with the SMU Law Review).

72. See, e.g., E-mail to author (Dec. 1, 2009, 08:38 MST) (on file with the SMU Law Review) ("Our bank said we make to much money and are current on our payments to we don't qualify for assistance. It is mostly fear that keeps us from sending them the keys."); E-mail to author (Dec. 2, 2009, 11:27 MST) (on file with the SMU Law Review) ("We have an investment home ... that is completely under water and have decided to walk away from it. We've also called the bank to ask for a modification but like many others, because we have always paid on time, they are of no help."); E-mail to author (Dec. 5, 2009, 06:56 MST) (on file with the SMU Law Review) ("I then attempted a loan modification but the lender would not agree to it unless I was 90 days late on payments-which I believed was morally wrong. I finally settled in on a path to short sale, and was forced to be 90 days late before the lender would accept a short sale offer... [M]y preference on short sale is that it seems like a good balance between release and responsibility."); E-mail to author (Dec. $12,2009,06: 42$ MST) (on file with the SMU Law Review) ("Because we are not it default with any of the lenders or credit card companies no one is willing to even talk to us about a restructuring program ...."); see also Christopher L. Foote, Kristopher T. Gerardi, Lorenz Goette \& Paul T. Willen, Reducing Foreclosures 2 (Fed. Res. Bank of Bos., Pub. Policy Discussion Paper No. 09-2, 2009) (explaining the economic incentives that cause lenders to refuse to negotiate with those who are current on their mortgages); Edmund L. Andrews, My Personal Credit Crisis, N.Y. TIMEs, May 17, 2009, at MM46 (describing the author's efforts to renegotiate his mortgage with his lender, including fact that lender informed him it would not discuss a loan modification until he was late on his payments). 
such accommodations. ${ }^{73}$ The best predictor that a homeowner will continue making payments is a good-credit score and a past history of making their payments. ${ }^{74}$ Homeowners with such characteristics, thus, have little chance of getting help unless they first miss some payments, and they are frequently told this by the loan-servicing personnel who take their calls: "My husband and I are also underwater and still paying. We have been trying to work out a modification or a refi with our bank for a year and a half. No success. Like so many others, it was implied that we would need to miss some payments first." 75

Homeowners are often unprepared for this fact, feeling that faithfully making their payments should have earned them their lender's goodwill and should make their lenders more likely to work with them:

So many of us are upside down in our homes and have no recourse unless we deliberately fall behind on our mortgage, there's no help from the mortgage company. So many times, I have called my mortgage company to say that I have been a good paying customer who despite these difficult economic times, have continued to pay on time. I am told over and over again that they cannot do anything for me. ${ }^{76}$

The fact that being a "responsible" borrower is the surest way not to get a loan modification can be a rude awakening for many homeowners. ${ }^{77}$ It can also be a first push toward strategic default:

73. See Foote, Gerardi, Goette \& Willen, supra note 72, at 2. ("Investors also lose money when they modify mortgages for borrowers who would have repaid anyway, especially if modifications are done en masse, as proponents insist they should be.").

74. See generally Manuel Adelino, Kristopher Gerardi \& Paul Willen, Why Don't Lenders Renegotiate More Home Mortgages? Redefaults, Self-Cures, and Securitization (Fed. Res. Bank of Atlanta, Working Paper 2009-17a, 2010).

75. E-mail to author (Jan. 14, 2010, 14:41 MST) (on file with the SMU Law Review). Many others also report being told they would have to miss payments before qualifying for help. See, e.g., E-mail to author (Jan. 27, 2010, 11:26 MST) (on file with the SMU Law Review) ("I want to consider walking away from my house. I did speak to my bank but they really have no interest in helping me as long as I continue to make payments."); Email to author (Nov. 29, 2009, 20:58 MST) (on file with the SMU Law Review) ("I am one of the unfortunate people who have had tried to work with my mortgage company, only to find that they wont help you if your not already in a distressed situation."); E-mail to author (Dec. 7, 2009, 19:57 MST) (on file with the SMU Law Review) ("I am about to be moved by my employer ... and Bank of America refuses to negotiate on any level with me. -Of course, because I am current and pay my mortgage on time."); E-mail to author (Dec. 8, 2009, 23:51 MST) (on file with the SMU Law Review) ("I was informed by Bank of America that the only way I would be able to refinance it would be by not making my payments and qualifying for Obama's mortgage assistance program."); E-mail to author (Feb. 16, 2010, 17:55 MST) (on file with the SMU Law Review) ("I have a person one day telling me not to pay my mortgage payment or else they won't modify the loan and then the very next day the same person telling me that she would 'never' have said that and that if I don't want to lose my house I better send in my payment.").

76. E-mail to author (Feb 1, 2010, 15:55 MST) (on file with the SMU Law Review).

77. See Foote, Gerardi, Goette \& Willen, supra note 72 ("Investors also lose money when they modify mortgages for borrowers who would have repaid anyway, especially if modifications are done en masse, as proponents insist they should be."); Adelino, Gerardi \& Willen, supra note 74, at 10 (explaining the economic disincentives for lenders to modify mortgage payments for borrowers who are current on their mortgages). 
We have contacted the bank several times to discuss this and they are not interested in negotiating anything different. This is really strange to me because we have excellent credit scores and a good income. But instead of renegotiating the terms of the deal, they will have to do all of the foreclosure paperwork, let the house stand empty, go to the expense of finding a new buyer, sell the house for $\$ 200,000$ less than we owed to folks who may or may not be as good credit risks as we are. This doesn't seem like a wise business decision to me but it is their decision. . . . I feel like I have been hit in the stomach . . . ${ }^{78}$

Another category of homeowners who rarely get help are those whose mortgage payments are $31 \%$ or less of their gross income. This is because the federal government has limited participation in most governmentsponsored loan-modification programs, such as Making Home Affordable (HAMP) and Hope for Homeowners, to individuals whose payments exceed this percentage. ${ }^{79}$ Moreover, these programs are generally designed to bring the borrowers monthly payments down to this $31 \%$ threshold and no less. ${ }^{80}$ This cutoff is purportedly based upon "[t]he generally accepted definition of affordability," 81 but does not sit well with many struggling homeowners who are denied relief as a result:

[I] tried to get the Home Loan Mod done thru our lender to no avail. Our small income of $\$ 33,000$ gross combined (I lost my $\$ 36,000$ yr. sales job earlier this year to lay-off) means to our lender we can afford an $\$ 850$ mortgage. So we don't qualify. The payment is $\$ 800$. Doesn't matter that I have 3 children from a previous [marriage] I'm supporting, which could almost cover the mortgage. Doesn't matter that electric and gas prices are up. Nothing matters but the bottom line, $31 \% .^{82}$

78. E-mail to author (Jan. 19, 2010, 10:00 MST) (on file with the SMU Law Review).

79. See Press Release, U.S. Dep't of the Treasury, Making Home Affordable: Updated Detailed Program Description (Mar. 4, 2009), available at http://www.treas.gov/press/releases/reports/housing_fact_sheet.pdf; Press Release, Making Home Affordable Program, Housing Program Enhancements Offer Additional Options for Struggling Homeowners (Mar. 26, 2010), available at http://makinghomeaffordable.gov/pr_03262010.html (setting $31 \%$ of annual income as the "affordability" cut-off).

80. See Press Release, Making Home Affordable Program, supra note 79, at 2.

81. See HUD, Affordable Housing, http://www.hud.gov/offices/cpd/affordablehousing/ index.cfm (last visited Oct. 10, 2010) ("The generally accepted definition of affordability is for a household to pay no more than 30 percent of its annual income on housing."). There are obvious problems with this definition of affordability, including that the $31 \%$ cut-off is largely arbitrary. Paying $31 \%$ of gross monthly income to a mortgage leaves many middleto-low-income individuals with little to spare, especially to the extent that individuals have other significant financial obligations such as child care expenses, credit card obligations, and medical bills.

82. E-mail to author (Dec. 3, 2009, 02:42 MST) (on file with the SMU Law Review); see also letter from a homeowner to Cong. Oversight Panel (Apr. 27, 2010) (on file with the SMU Law Review) ("[After 6 months of making trial payments], I received a letter from Citimortgage ... informing me that I was at risk of losing my eligibility under the program because Citimortgage had concluded that my monthly housing costs were less than $31 \%$ of my gross monthly income."). An opposing variant of this $31 \%$ problem are homeowners who are denied modifications under HAMP because $31 \%$ of their income is not enough to make a modification worthwhile (though lenders are required to reduce payments to that amount under HAMP). See, e.g., E-mail to author (Apr. 30, 2010, 09:05 MST) (on file with the SMU Law Review) ("[T] he mortgage servicer was uninterested in 
A narrow exception to the $31 \%$ rule is the Making Home Affordable Refinancing Program, which is supposed to allow underwater homeowners to refinance up to $125 \%$ of their home's current value at "today's lower interest rates," 83 if they are current on their mortgage and if Freddie Mac or Fannie Mae holds their loan. ${ }^{84}$ Aside from the fact that refinancing at today's rates may have only a negligible effect on an underwater homeowner's mortgage payment, many underwater homeowners have loan-to-value ratios that are much higher than $125 \% .{ }^{85}$ Indeed, the $125 \%$ cutoff means that the very homeowners who are the most likely to be distraught about their negative equity's extent are the least likely to get help. ${ }^{86}$ Rather, they are rejected at the outset due to high loan-to-value ratios:

I have also contacted Making Home affordable.gov website and a counselor told me that as my loan is not a Fannie Mae loan and I am over $125 \%$ underwater due to severe decline in [my housing] market, I am not eligible for any assistance and I should contact Chase directly, which I have already done and was refused. ${ }^{87}$

Underwater homeowners who are not refused from the start are typically invited to submit applications for loan modifications, often with the suggestion that they may qualify for either HAMP or Hope for Home-

talking to me as long as i didn't have a job. i laugh at obama's proposal to have unemployment considered as income. $i$ am getting $2 \mathrm{~K} /$ month. $31 \%$ of that is a very small fraction of my former mortgage payment. what lender would ever agree to that?").

83. Borrower Frequently Asked Questions, MAKINGHomeAFFordable.gov, http:// makinghomeaffordable.gov/borrower-faqs.html (last visited Oct. 28, 2010).

84. Press Release, Making Home Affordable, Secretary Donovan Announces Expanded Eligibility for Making Home Affordable Refinancing (July 1, 2009), available at http://makinghomeaffordable.gov/pr_07012009.html.

85 . In the Fourth Quarter of 2009 , over $10 \%$ of all homeowners with a mortgage owed more than $25 \%$ of what their homes were worth. First American Core Logic, Negative Equity Report (Feb. 23, 2010), available at $\mathrm{http} / / \mathrm{www}$.loanperformance.com/infocenter/library/Q4_2009_Negative_Equity_Final.pdf. In Nevada, over half of homeowners were more than 25\% underwater, approximately $30 \%$ were underwater in Arizona and Florida, and approximately $20 \%$ were underwater in California. Id. Nationally, the Fourth Quarter 2009 value of all negative equity totaled $\$ 801$ billion, with $\$ 660$ billion of this concentrated in homes with at least $25 \%$ negative equity. Id.

86. See Bhutta, Dokko \& Shan, supra note 8 , at 7 (finding that the average strategic defaulter has $62 \%$ negative equity).

87. E-mail to author (Dec. 7, 2010, 13:02 MST) (on file with the SMU Law Review); see, e.g., E-mail to author (Dec. 24, 2009, 21:49 MST) (on file with the SMU Law Review) ("I've probably gone through the process of trying to refinance once every 6 months for the past 2 years, but have always been told my property doesn't appraise at a high enough value to qualify for any loan programs. I've also asked both of my current mortgage holders if they would be willing to reduce the interest rate on my loan without any success."); E-mail to author (Feb. 4, 2010, 11:40 MST) (on file with the SMU Law Review) ("I requested .... an amortizing loan. It was either refinance or I would walk. The first thing they mentioned was that it would kill my perfect credit score. After reviewing my income and debt, they said I didn't qualify for any TARP funds because my income was too high compared to my mortgage payment and I couldn't refinance because my loan balance exceeded the value of my house by more than 125\%."); E-mail to author (Dec. 10, 2009, 12:29 MST) (on file with the SMU Law Review) ("We bought a home in 2006 for $\$ 415 \mathrm{k}$, putting down $\$ 100 \mathrm{k}$. We recently tried to refinance to lower our fixed rate from 5.75 to 4.35 but were denied as the appraisal came in at only $\$ 220 \mathrm{k}$. Ridiculously low. They want us to bring in $\$ 137[\mathrm{k}]$ cash to refinance."). 
owners. ${ }^{88}$ The loan-modification process turns out, however, to be immensely frustrating and ultimately unsuccessful for many homeowners. ${ }^{89}$

First, homeowners are frequently unable to reach anyone to discuss their applications' statuses:

I submitted my first modification request/proposal (which included a principal reduction to the then-current local market value) in January, followed by an addendum to that request in February. I called ... and called ... and called, trying to follow up, all to no avail. I continued making my payments, on both loans through April, and submitted another package, all the while telling both lenders that, after the April payments, I would have no money left. I received no response at all until I became delinquent for the May payments. ${ }^{90}$

Their paperwork is "lost" repeatedly:

After losing my job in Jan last year, I set up an appt and application with HOPE in late April - and have yet to receive a decision from Chase about my home modification request (they've lost my info 5 times and are the most unprofessional, unqualified group I've had to deal with)..$^{91}$

They are treated rudely and lied to:

"I cannot count the number of times I have called BOA and been treated rudely, lied do, disconnected, sent to wrong extensions, etc. . .Consequently, you can imagine the frustration I am feeling. I rue the day I even considered modification." 92

They are threatened:

88. See, e.g., E-mail to author (Jan. 31, 2010, 14:07 MST) (on file with the SMU Law Review) ("[The Freddie Mac representative] told me that I didn't qualify for any modifications currently available, but to submit a new package, which I did.").

89. The problems with the HAMP and Hope for Homeowners loan modification process have been documented by other academics, but it is helpful to hear about them in homeowners' own words in order to truly get a sense of the emotions the loan modification process engenders. For an excellent discussion of the various problems with HAMP, see Jean Braucher, Humpty Dumpty and the Foreclosure Crisis: Lessons from the Lackluster First Year of the Home Affordable Modification Program (HAMP) (Ariz. Legal Studies, Discussion Paper No. 09-37, 2010).

90. E-mail to author (Jan. 31, 2010, 14:07 MST) (on file with the SMU Law Review). Others share similar experiences. See, e.g., E-mail to author (Dec. 14, 2009, 10:35 MST) (on file with the SMU Law Review) ("I have tried to work with my lender (Citimortgage) to attempt to get a reduction in the interest rate however they are impossible to get a hold of much less work with. I have seriously contemplated purchasing another apartment in the same complex where I own mine and default on this one because I am not able to refinance and they will not reduce interest."); E-mail to author (Jan. 23, 2010, 12:35 MST) (on file with the SMU Law Review) ("I've contacted the bank many times to discuss a modification to no avail. Its more like person reading a script than any true thinking.").

91. E-mail to author (Dec. 8, 2009, 15:57 MST) (on file with the SMU Law Review); see also E-mail to author (Nov. 28, 2009, 07:26 MST) (on file with the SMU Law Review) ("After dealing with a balloon mortgage myself and having the bank 'lose' my modification paperwork 3 times, I became wise to their game.").

92. E-mail to author (Feb. 3, 2010, 12:42 MST) (on file with the SMU Law Review); see also E-mail to author (Nov. 30, 2009, 12:13 MST) (on file with the SMU Law Review) ("My loan servicer routinely, regularly and knowingly lied to me about the legal and tax consequences of my own default in their attempts to get me to pay in full in spite of being $800,000.00$ upside down."). 
"[A]ll this time, I was trying to work with someone ... anyone ... to figure something out so I could stay in my house, however, it became painfully obvious to me that the lenders just weren't interested in working with me, other than to make threatening phone calls." 93

And, they are forced to wait for months for an answer. ${ }^{94}$

Worse, after months of frustration, most homeowners learn that their lender is not willing to work with them after all:

In summation, I began this process with the hope of being able to keep my home by lowering my monthly mortgage payment. At that time, I was told that the worst case scenario was that I would be rejected and would be in no worse financial standing than when I began the process. As it stands right now, eleven months later: I am listed as being delinquent on my mortgage; my credit history has been damaged; I have lost access to several thousand dollars in unsecured debt; none of my phone calls to Citimortgage attempting to resolve these issues have been returned; I have instead only received letters threatening acceleration and foreclosure; and now I have been supposedly rejected from [HAMP] based on grossly inaccurate information. ${ }^{95}$

93. E-mail to author (Jan. 31, 2010, 14:07 MST) (on file with the SMU Law Review); see also E-mail to author (Feb. 16, 2010, 17:24 MST) (on file with the SMU Law Review) ("Their collections department continues to threaten actions towards foreclosure despite the fact that I am told I am in the trial period.").

94. E.g., E-mail to author (Feb. 5, 2010, 08:38 MST) (on file with the SMU Law Review) ("I started their painful 'process' on March 27, 2009. It is now February 2010 and we have still not received the help of a modification."); E-mail to author (Nov. 30, 2009, 07:09 MST) (on file with the SMU Law Review) ("Meanwhile, six months later, my agent was still unsuccessful in getting Countrywide to move off first base with a short sale, and he walked away from the matter. I allowed the home to go into foreclosure at that point since I could not do a deed in lieu to Countrywide because of the second mortgage on the house."); E-mail to author (Nov. 29, 2009, 20:58 MST) (on file with the SMU Law Review) ("We tried to short sale our house and had 2 offers at the amount the mortage company... wanted. After 6 months of waiting for there approval, they sold our loan to an even more terrible company.... Needless to say we have walked away from the house and are now renting one. We tried to save our house and our credit since Aug 2008, but like you already know, the mortgage companies have other agendas.").

95. Letter from a homeowner to Cong. Oversight Panel (Apr. 27, 2010) (on file with the SMU Law Review). This homeowner account is far from atypical. E.g., E-mail to author (Dec. 1, 2009, 14:26 MST) (on file with the SMU Law Review) ("I have been trying to work with my former servicer and most recently Bank of America (my mortgage servicer sold it to them last year) for almost two years now, ever since my husband lost his construction job in the very beginning of the recession. I was stonewalled by all the usual excuses you've heard (lost paperwork, wrong paperwork, not enough people, new rules, new programs etc ad naseum) and lied to, patronized, castigated, hung up on, transferred endlessly, shamed and ignored finally. I could never escalate my case beyond CS reps in India."); E-mail to author (Dec. 7, 2010, 13:02 MST) (on file with the SMU Law Review) ("My Lender Chase is giving me a very hard time for more than year now, although I meet all the guide lines for loan modification set forth by the Obama administration. I have completed all of their required paperwork and submitted every document they asked, but still Chase refused because I am current on my monthly mortgage payments. Chase has offered me no alternative plan or suggestions to assist me in anyway."); E-mail to author (Dec. 20, 2009, 14:42 MST) (on file with the SMU Law Review) ("I am in the final stages of attempted negotiations with [my mortgage companies] for a house ... that is over $50 \%$ underwater. . . . All I have asked for is a fixed rate loan-no modification to the mortgage value—and still the answer remains steadfastly 'NO.' "); E-mail to author (Nov. 18, 2009, 
Those who are offered loan modifications, on the other hand, are frequently offered ones that don't make any financial sense in that they barely reduce the monthly payment, they increase the homeowner's negative equity, or both: 96

I tried to get Citi to modify my loan due to unemployment, an interest only loan, and an upside down house to the tune of $\$ 300,000.00$. After being lied to, manipulated, making trial payments that they said were the precurser to the permanent loan and then having them cancel that program, I managed to get them to lower our payment $\$ 160.00$ per month. They tacked on $\$ 35,000.00$ to the backend of the loan in the process. I did the math and it is gonna cost us another $\$ 175,000.00$ in interest in addition to the previous debt (if we pay it off) to save $\$ 9600.00$ over ten years. . . We are walking. ${ }^{97}$

The few homeowners who are offered financially-meaningful trial modifications are usually dismayed to learn that their lender will report them as delinquent during the trial period: ${ }^{98}$

The program they have given us is called the Freddie Mac "Making Home Affordable" program and ... we were awarded the trial pe-

10:21 MST) (on file with the SMU Law Review) ("I started to attempt to negociate a refinance to a straight 30 year amortised note. Since Feb. I have had numerous conversations with the mortgage company and in late Sep. after getting nowhere, I decided to walk away."). These stories are consistent with what the statistics tell us about likelihood of a lender modifying a mortgage. See Adelino, Gerardi \& Willen, supra note 74, at 3 (noting that "lenders rarely renegotiate" and that only $3 \%$ of seriously delinquent mortgages in their study had received "concessionary modifications" in the previous year).

96. See Cong. Oversight Panel, October Oversight Report: An Assessment of Foreclosure Mitigation Efforts After Six Months 25 (2009) (finding that the average loan modification increases the homeowner's negative equity).

97. E-mail to author (Feb. 16, 2010, 17:55 MST) (on file with the SMU Law Review). Others report receiving similarly disappointing offers. E.g., E-mail to author (Dec. 7, 2009, 14:27 MST) (on file with the SMU Law Review) ("I have been working with the bank since Feb to refinance or restructure the loans, specifically since our businesses have been struggling) and finally just got the payment reduced $\$ 173$ month. If we default, we have to default on both homes, right?"); E-mail to author (Jan. 23, 2010, 20:41 MST) (on file with the SMU Law Review) ("Well, things happened and wasn't able to refinance so we tried to remodify and the lender made things even worse for us. First [our lender] put us in a interest only loan for 30 years at a $13.4 \%$ and now our payment is $\$ 2500.00$ for a $200,00.00$ loan. We really had no choice but to walk away since the company really won't work with us and we are around $\$ 60,000.00$ underwater."); E-mail to author (Feb. 16, 2010, 17:24 MST) (on file with the SMU Law Review) ("The amount of money piling up to be added on the 'back of my loan?' or paid immediately is now reaching $\$ 6,000.00$. With the additional $\$ 6,000.00$ to my mortgage my loan if now for $\$ 159.000 .00$."); E-mail to author (Feb. 19, 2010, 09:11 MST) (on file with the SMU Law Review) ("Can you help me understand why people in desperate need of help are being sent documents that they will feel compelled to sign that doesn't address the basic questions of their serious problem."); E-mail to author (Nov. 30, 2009, 22:30 MST) (on file with the SMU Law Review) ("We tried for nearly 8 months to negotiate a principal reduction, only to be told that Freddie Mac NEVER reduces the principal.").

98. See Joseph Boven, Fed's Mortgage Modification Program: Keep Your House, Lose Your Credit, Colo. INDEP. (April 8, 2010, 9:29 AM), http://coloradoindependent.com/ 50487/feds-mortgage-modification-program-keep-your-house-lose-your-credit ("Although the program, known as HAMP, works to reduce monthly mortgage payments by half or one-third of monthly income, the program can also ruin participants' credit for years to come" because lenders report borrowers as delinquent during the trial modification period.). 
riod of this loan modification program. I was very upset when I received the paperwork describing this program. It is a 6 page document that describes the program. . . [One] section entitled "Credit Reporting" [reads:] "During the trial period, we will report your loan as delinquent to the credit reporting agencies even if you make your trial period payments on time. However, after your loan is modified, we will only report the loan as delinquent if the modified payment is not received in a timely manner." This seemed very unfair to me. My son has been making all the payments on this loan since it's inception ... both of our FICO credit scores were high (mine being 840). Because of this statement in the paperwork sent to us, I started making the original $\$[1000]$ payment, while my son made the "trial period" payment of $\$[400]$. Both payments were made [for the first five months]. I am now unable to make the original \$[1000] payment because I still have not been able to get a job. ${ }^{99}$

Being reported late during the trial period defeats a primary purpose of a loan modification for many underwater homeowners, namely preserving their credit. Learning that accepting a trial-loan modification will ruin their credit thus compels some to give up the idea of a loan modification altogether:

What many people don't know when they apply for this type of modification, is that the banks cash your mortgage checks and place these funds in a separate file. The monies are not applied to your account. Therefore, in the months that pass by, your account is reported as delinquent to the credit bureaus .... an acquaintance learned the hard way. When I heard this information, I feared my credit would be ruined as well, and cancelled my modification request. ${ }^{100}$

Those who nevertheless accept trial modifications find that they get stuck in them for months with no indication from the lender as to when, if ever, they will become permanent:

I have been waiting for a home modification to go through, and have made (13) Trial Payments since June of 09. During that

99. E-mail to author (Feb. 5, 2010, 08:38 MST) (on file with the SMU Law Review) (the author approximated the homeowner's actual mortgage payment to preserve confidentiality). Some report having their loans reported delinquent during the trial period even after being promised they would not be. E.g., Letter from a homeowner to Cong. Oversight Panel (Apr. 27, 2010) (on file with the SMU Law Review) ("I investigated my credit report and discovered that a [large] delinquency had been placed on my account by Citimortgage. Under the HAM Program, on the Making Home Affordable website (www.makinghomeaffordable.gov), it is clearly stated that "If you are current with your mortgage payments prior to the trial period and make each trial period payment on time, your servicer must report you as current and also identify the loan as modified under federal government plan." .. . The Equifax report does not show that Citimortgage identified "the loan as modified under federal government plan" as required by the HAM Program. I have never been told by Citimortgage as to when or why Citimortgage did this to my credit report. As a result of Citimortgage's action, my credit has been negatively affected which is a direct contradiction of what was told to me by the Citimortgage representatives, as I indicated at the beginning of this complaint summary. Except for this supposed delinquency on my account, I had never missed a scheduled payment to Citimortgage and have maintained excellent credit.").

100. E-mail to author (Feb. 3, 2010, 12:42 MST) (on file with the SMU Law Review). 
timeframe, it has been as if my loan has been under a shrouad of secrecy where I am totally at the mercy of the lender. The trail was supposed to only last three months, and, here I am, 13 months later, with what feels like "no end in sight". Yes, I am willing to go through the pain, stress, and the secrecy, since the carrot BofA dangles in front of me is the hope of a reduced mortgage payment ... but they, even now, they benefit by dragging things out, to the point where they are oblivious to what being in limbo for over a year can do to a person-or are they? 101

\section{Most trial modifications never do become permanent. ${ }^{102}$}

The emotional impact of being flatly refused help, or learning after months of waiting that the initial hope was false, is enough to push many underwater homeowners from a state of anxiety to a state of despair. ${ }^{103}$ The name of the government program "Hope for Homeowners" wisely reflects an understanding that, to hold on, homeowners must have hope. The cruel irony for many underwater homeowners, however, is that signs of hope are few and far between.

101. E-mail to author (Apr. 30, 2010, 11:06 MST) (on file with the SMU Law Review). Others report similar experiences. E.g., E-mail to author (Jan. 14, 2010, 22:19 MST) (on file with the SMU Law Review) ("I made my initial 3 trial payments last year, and was initially due to receive new loan docs by October 09 . Well, here it is the end of January, and I am still making trial payments with still no assurance that my modification is going to go through. ... Even now, something inside of me is thinking the modification will not really help me (the terms, after 8 months worth of trial payments, are still a mystery to me they are just telling me to 'keep doing what I am doing') and that in the end I might be forced to, or should even now consider 'walking away' anyway."); E-mail to author (Feb. 16, 2010, 17:24 MST) (on file with the SMU Law Review) ("I am now 10 months into a request for a loan modification under the President's 'Making Homes Affordable' program and I fear that no matter what steps I take I will still loose my home and my ability to ever be out of debt. I have been paying my 'Trial Payment' since August of 2009."); E-mail to author (Feb. 5, 2010, 08:38 MST) (on file with the SMU Law Review) ("We are still in the trial period and don't know how much longer this process is going to take. I don't want to walk away from this loan but I am tempted.").

102. See, e.g., Renae Merle, Geithner Vows Crackdown on Lenders, Wash. Post, Apr. 30, 2010, at A17 "So far, the federal program, known as Making Home Affordable, has helped about 200,000 borrowers get a permanent loan modification. But the government is far short of helping the 3 million to 4 million homeowners it initially targeted. In the meantime, millions of homeowners are expected to fall into foreclosure over the next few years."); see also E-mail to author (Jan. 14, 2010, 22:19 MST) (on file with the SMU Law Review) ("I am presently part of the Making Home Affordable Program (so I am not walking away), and while it is looking promising that our loan will be modified, reports are that only 1 to 2 percent of modifications actually do go through, which, at the same time does not allow me to become to optimistic.").

103. E.g., E-mail to author (Jan. 14, 2010, 13:17 MST) (on file with the SMU Law Review) ("I have lost everything and am extremely depressed . ..."); E-mail to author (Apr. 30, 2010, 11:06 MST) (on file with the SMU Law Review) ("[A]t this point [I] feel like I'm dying a bit inside."); E-mail to author (Dec. 7, 2009, 13:02 MST) (on file with the SMU Law Review) ("[I'm] losing hope from every side ....."); E-mail to author (Dec. 1, 2009, 07:59 MST) (on file with the SMU Law Review) ("I just do not know what to do."); see also Streitfeld, supra note 1, at 2 (reporting on the increase in homeowners walking away, and quoting one mortgage broker as explaining, "Everyone has lost hope. They don't qualify for modifications, and being on the hamster wheel of paying for a property that is not worth it gets so old."). 


\section{ANGER}

Hopelessness and despair, however, don't tend to motivate action. While they might cause some homeowners to just give up and stop making payments, most homeowners need something more to get them over the guilt, shame, and fear that keep them from walking away. ${ }^{104}$ That something more for many strategic defaulters is anger.

Homeowners who are deeply underwater with no apparent way out frequently become resentful and angry about their predicaments. While they may blame themselves for buying their homes at the wrong time, ${ }^{105}$ strategic defaulters tend to direct most of the blame, and thus their anger, toward financial institutions and the government for causing, or allowing, the housing meltdown. ${ }^{106}$

This anger is only compounded by the sense that their lenders are giv-

104. See White, supra note 6 , at 21 . While the role of shame and guilt in constraining default were discussed above, some homeowner accounts give a sense of fear. E.g., E-mail to author (Dec. 1, 2009, 08:38 MST) (on file with the SMU Law Review) ("Our bank said we make to much money and are current on our payments to we don't qualify for assistance. It is mostly fear that keeps us from sending them the keys. Fear of damaged credit, fear of the bank coming after us, and fear of excess income taxes should we make that move."); E-mail to author (Jan. 27, 2010, 10:24 MST) (on file with the SMU Law Review) ("I have 2 properties . . . They are both rented. The values on each are around $\$ 85,000$ and the loan on one is around $\$ 195,000$ and the other $\$ 175,000$. So they are both seriously underwater. I would walk away in a second, but as I understand [my state] law, it is a recourse state."); E-mail to author (Dec. 21, 2009, 07:07 MST) (on file with the SMU Law Review) ("My husband and I had agonized for about a year of what to do with our underwater situation-we pulled the trigger a couple of months ago, and yes, one of the many variables that we had to overcome was the fear of the effect on our great credit and our prospects for future employment."); E-mail to author (Dec. 24, 2009, 21:49 MST) (on file with the SMU Law Review) ("I . . . have not walked away from my property for fear of the legal consequences. ... My main concerns are that $I$ have a secure job and a high income. I worry that the banks would identify me as someone with means to continue making payments and pursue further action against me.").

105. E.g., E-mail to author (Dec. 7, 2009, 12:42 MST) (on file with the SMU Law Review) ("We made this foolish decision [to buy a second home] when the real estate market was strong. Needless to say, we got caught in the quite abrupt transition of good market to bad market.").

106. See, e.g., E-mail to author (Nov. 30, 2009, 19:17 MST) (on file with the SMU Law Review) ("We were not stretching for our home and we knew that the market may not stay as healthy back in 2005. But no one except insiders knew that this market was going to collapse to the degree it did. So to pass the blame of the mortgage crisis on all homeowners and act like $100 \%$ of them were on adjustable loans with little down payments is crazy and insulting."); E-mail to author (Jan. 5, 2010, 15:21 MST) (on file with the SMU Law Review) ("I think you can imagine the four letter words I often use to describe my feelings toward the bankers who artificially pumped up housing prices for the past 5-10 years."); $\mathrm{E}$ mail to author (Jan. 27, 2010, 09:57 MST) (on file with the SMU Law Review) ("The United States Government has allowed this banking atrocity to unfold and are still not willing to cleanse the system of the wrong it perpetrated and gained from. The banks allowed for loans to be made, they sold them and profited, they have been saved from there due burden in the crisis and they continue to manipulate the finance market while at the same time have been allowed to ruin the credit of the very people who can and will eventually, save the housing industry. How can our Government not see this."); E-mail to author (Feb. 1, 2010, 15:55 MST) (on file with the SMU Law Review) ("We all bought our homes as we are told that this is the 'American Dream' and 'the single most investment we will ever make in our adult lives'. We all expect our homes to appreciate but due to the irresponsible behaviors or the bankers, Wall Street, greedy real estate brokers and agents, our single most important investment has turned into a nightmare."). 
ing them the runaround, ${ }^{107}$ being callous and uncaring, ${ }^{108}$ looking out only for their own economic self-interest, ${ }^{109}$ and refusing to help despite being bailed out by taxpayers themselves. ${ }^{110}$ This anger turns out to be cathartic for many strategic defaulters, relieving their guilt and justifying a tit-for-tat response to banks for their profit-driven behavior:

I also have [Citi] laying out the terms of the loan mod, my canceled checks and receipts to show I followed their instructions right down the line, and then them cancelling the deal after they got the three trial payments cause the "investor" didn't participate in the program-this was discovered after they got the money and after they cashed the checks of course. As it turned out the mysterious "investor" was actually Citi. They didn't know that they couldn't participate and they were the participants. What a total screw job. So yes they can eat their house being upside down with no guilt from us. ${ }^{111}$

107. E.g., E-mail to author (Dec. 1, 2009, 17:57 MST) (on file with the SMU Law Review) ("My husband and I are middle class hard working people that got caught up in the mortgage melt down. We bought our first home $3+$ years ago $100 \%$ financing $3 / 1$ IO for $\$ 560,000.00$. We paid our payment 3 years on time even when the value went down to $\$ 260 \mathrm{k}$ still owing $\$ 560 \mathrm{k}$. When our rate adjusted and went up we reached out to our Mortgage lender asking for a modification and after 6 months of the "run" around we were turned down. ... If they choose not to help my family and work out an agreement for all parties involved, they can have the home!!!").

108. E.g., E-mail to author (Dec. 11, 2009, 18:02 MST) (on file with the SMU Law Review) ("I have no moral connection to [my mortgage company] as they don't care for me or my family.").

109. E.g., E-mail to author (Nov. 30, 2009, 22:30 MST) (on file with the SMU Law Review) ("Everything they do is a business decision, as was my decision to walk away from a home that was over $\$ 200,000$ underwater. Hopefully more articles like yours will convince others to do the same. It's not personal, Wells Fargo . . . it's just business."); E-mail to author (Feb. 18, 2010, 17:09 MST) (on file with the SMU Law Review) ("As far as the double standard between Main St (homeowners) and Wall Street (lenders/bankers), what is really unfair is the lenders of underwater loans continue to PROFIT AT HIGHER levels from inflated principals while homeowners are faced negative equity the foreseeable future.").

110. E.g., E-mail to author (Nov. 30, 2009, 12:50 MST) (on file with the SMU Law Review) ("With the banking industry given a clean slate, money to burn and still outrages bonuses why should she have to struggle while others continue to live the high life that have created this financial mess."); E-mail to author (Dec. 21, 2009, 07:07 MST) (on file with the SMU Law Review) ("Additionally, I personally (my husband is also coming to this conclusion) put a great deal of blame on the banks in the first place and do not believe that individual borrowers, like us, should have to bear the burden of the mess these institutional players created, which led us, in part to purchase our home at the height of the bubble.").

111. E-mail to author (Feb. 16, 2010, 17:55 MST) (on file with the SMU Law Review). Many others revealed similar sentiments. E.g., E-mail to author (Dec. 5, 2009, 13:42 MST) (on file with the SMU Law Review) ("[L]enders are not living up to any implied sense of personal/social/moral responsibility, so I certainly wouldn't have any qualms about screwing over Wells Fargo knowing full well that if I don't screw them, they will screw me."); Email to author (Nov. 29, 2009, 13:42 MST) (on file with the SMU Law Review) ("The banks, lending institutions, and realty and mortgage brokers have demonstrated nothing but egregious self interest in pursuing profits at all costs to the consumer in this country. I took a hike from a mortgage that turned out to be a nightmare for me - they can take a hike now."); E-mail to author (Jan. 19, 2010, 09:55 MST) (on file with the SMU Law Review) ("I applied for the HAMP program and just found out yesterday from Wachovia that I wasn't approved. I'm assuming I wasn't approved because I've never missed a payment. It pisses me and I want to say screw you and live her for free as long as I can until they kick 
One way to understand the emotional process is by realizing that blaming someone or something else helps many strategic defaulters manage the troublesome emotions such as guilt, shame, and a sense of failure that are associated with default. It is, in a sense, a dissociative move-blame their lender, "Wall Street," or the "government." All of these may in fact be to blame, but the appeal may be less about rational analysis than managing emotions. To spare themselves, strategic defaulters "turn the gun outward." 112

In addition to becoming angry about their unfair situations, some strategic defaulters become angry because they feel that everyone else is getting help but them: "[F]rankly, we are tired of getting the short end of the stick while the government seems to rescue everyone but us."113 "Congress and the new transparent Administration needs to raise it's moral compass and quit bowing to the special interest groups and making sweet deals that propel their career on the backs of hardworking Americans. I am fed up. ..."114

The outrage at being left out is heightened for some by their perception that they, as "responsible" homeowners, get nothing, while "irresponsible" homeowners get undeserved assistance:

All the advice seems to be for those who got crazy loans or kept getting equity out of their home. What about those of us who put MORE than $20 \%$ down and got conventional loans without refinancing ever.... I feel as if I've been stolen from!! People just tell me I was dumb for putting so much money down - well shame on me for not getting an interest only loan! I can afford my payments but I am PISSED! Any suggestion on what people like me can do? One of my coworkers who got a "Funny loan" received a letter from her 2nd mortgage saying they were taking thousands of dollars off of her principle without her even asking!! Where is MY principle reduc-

me out and then have my parents by me a home with their credit in a year from now at a great deal.").

112. E-mail from Toni M. Massaro, Regents' Professor, Milton O. Riepe Chair in Constitutional Law, \& Dean Emerita, Univ. of Ariz., James E. Rogers Coll. of Law, to author (May 8, 2010, 16:48 MST) (on file with the SMU Law Review). Other homeowners likely blame themselves too much; they are unable to see that they are not alone at fault. Id. These homeowners "turn the gun inward" and may be less likely to walk away. Id.

113. E-mail to author (Jan. 8, 2010, 10:25 MST) (on file with the SMU Law Review).

114. E-mail to author (Dec. 10, 2009, 12:29 MST) (on file with the SMU Law Review); see also E-mail to author (May 3, 2010, 07:02 MST) (on file with the SMU Law Review) ("If you bail out financial institutions, then certainly there should be an obligation to bail out the people that the financial institutions used and the people whose money you used for the bailout."); E-mail to author (Nov. 18, 2009, 22:21 MST) (on file with the SMU Law Review) ("[T]he housing crash is being unfairly put upon the backs of home owners. . . [I]n my case the medias constant reporting of the billions given to bailout banks, Investment corps, et al. made a huge impact on my decision."); E-mail to author (Dec. 21, 2009, 07:07 MST) (on file with the SMU Law Review) ("Finally, though I support my President, he needs to get a clue (of course, I mean policy makers, in general). The lame attempts to have banks modify loans are just a drop in the bucket. ..."); E-mail to author (Nov. 30, $2009,22: 30$ MST) (on file with the SMU Law Review) ("We voted for Obama based on his support for the cramdown legislation. However, once elected, he didn't put any support behind it."). 
tion!! I like my home but I'm so pissed that people like me (and I know there is more than me out there) are getting screwed! ${ }^{115}$

But whether they direct their anger at the government for helping out others and not them, or at their lenders for refusing to negotiate, anger at the perceived injustice of their situations drives many underwater homeowners to feel justified in walking away:

I háve tried in every way possible to do the "right" thing, but have been rebuffed at every turn. THAT is why I am walking away. It is purely a business decision on my part now. How can we be expected to "honor our obligations" when, even when we try to and want to, our efforts are denied? Just because it is "better business" for them to foreclose? How about that for a double standard? ${ }^{116}$

\section{RELIEF AND A SENSE OF EMPOWERMENT}

After all the guilt, anxiety, despair, and anger, the actual act of strategic default brings many underwater homeowners a sense of empowerment:

So the decision has been made, my last payment was in December. I called and told them I wasn't paying anymore and this time requested an $\$ 80 \mathrm{k}$ principal reduction and an amortizing loan. Of course I didn't hear from them until I was 30 days delinquent. When they called to collect, the script was predictable: she threatened my credit would be negatively affected, I would have to repay missed payments with penalties and interest, they would take my home, and I would risk losing other assets. I sensed her frustration when I told her to go ahead and begin the process if they weren't going to restructure. It felt great to take away their leverage! ${ }^{117}$

115. E-mail to author (Mar. 17, 2010, 08:40 MST) (on file with the SMU Law Review); see also E-mail to author (Feb. 3, 2010, 12:42 MST) (on file with the SMU Law Review) ("This home modification promise is full of holes and wreaks havoc on our citizens. . . [S]omebody has to stop this. Somebody in our administration must investigate this. I have written to Channel 3 and Channel 5, as well as Senator John McCain. I have yet to receive a response.").

116. E-mail to author (Dec. 1, 2009, 14:26 MST) (on file with the SMU Law Review). It should be noted that the study by Guiso, Sapienza, and Zingales found no correlation between homeowners' anger about the economy and their attitudes about default. See Guiso, Sapienza \& Zingales, supra note 8, at 20 . However, the accounts of homeowners discussed in this article suggest that the study asked the wrong question. The study asked, "On a scale from 1 to 5 with 1 being 'not angry at all' and 5 being 'very angry,' how angry are you about the current economic situation?" Id. at 13. A better question would have been: "How angry are you about the way the government has dealt with homeowners like you who are underwater on their mortgages?" It is not general anger about the economy than drives people to default; it is anger about the way that they personally have been treated-or left to fend for themselves while others get bailed out-that drives some homeowners to default.

117. E-mail to author (Feb. 1, 2010, 23:16 MST) (on file with the SMU Law Review); see also E-mail to author (Apr. 29, 2010, 22:33 MST) (on file with the SMU Law Review) ("When I tell them that I have already secured another house . . . and that my wife has an 820 credit rating (the mortgages were in my name only), they just sputter and try the moral high ground story. I tell them the house is in very good shape and ready for foreclosure, 
Moreover, strategic defaulters frequently report feeling relieved once the process is finally over. ${ }^{118}$ As one homeowner explained, "Choosing to walk away was the hardest thing I think I've ever battled with. After walking away, I have felt nothing but relief." 119 This relief is especially powerful to the extent that homeowners have already psychologically let go of their emotional attachments to their homes and feel trapped in a hole from which they would like to escape. ${ }^{120}$ Like a person who finally leaves an unhealthy relationship after years of wanting to do so-or as one homeowner described it, "our abusive husband, our mortgage company"-they report feeling free again and hopeful about the future. ${ }^{121}$

Understanding this relief helps explain why the self-cure rate for those who become delinquent on their mortgages has dropped from $45 \%$ in the early part of the decade to $6.6 \%$ today. ${ }^{122}$ Having been pushed to make the psychological break from all the shame, guilt, and fear that kept them from defaulting on their mortgages, most strategic defaulters have no desire to go back. Indeed, having already lost their good-credit score, they have little to gain by doing so: "Given the damage already done to my credit rating, the pain of going through further negotiations, and a deployment for 9 months to Afghanistan, I just don't have the time or energy to see if anything can be worked out-especially since I am not

and to please hurry up and get on with it. That really frustrates them to no end. It is very, very good to have options.").

118. The process of strategically defaulting itself can be extremely difficult psychologically. E.g., E-mail to author (Nov. 30, 2009, 12:13 MST) (on file with the SMU Law Review) ("I can tell you first hand, that defaulting personally is nothing less than extraordinarily emotionally distressing even in spite of my occupationally advanced understanding of my own legal rights as a borrower."); E-mail to author (Dec. 11, 2009, 09:15 MST) (on file with the SMU Law Review) ("It can be a very lonely, isolating and psychologically challenging process ...."); E-mail to author (Dec. 4, 2009, 16:21 MST) (on file with the SMU Law Review) ("I'm finally over the emotional trauma so I'm ready to think with dollars and sense.").

119. E-mail to author (Nov. 17, 2009, 10:27 MST) (on file with the SMU Law Review).

120. See Bhutta, Dokko \& Shan, supra note 8 , at 5,28 (noting that default would be more costly for those who have become emotionally attached to their homes); Mark Whitehouse, American Dream 2: Default, Then Rent, Wall St. J., Dec. 16, 2009, at A1. (reporting that many underwater homeowners now dream of getting out from under their homes and renting); see also E-mail to author (Nov. 30, 2009, 07:09 MST) (on file with the SMU Law Review) ("As for the effect on me after deciding to walk, I knew the foreclosure would hurt my credit rating for a while. However, I continued to remain current on other debt obligations, including personal lines of credit and a credit card. After HSBC started pursuing me for the $\$ 40,000$ I owed it on the second deed of trust, I then decided a year later to file for Chapter 7 bankruptcy. I reaffirmed my other credit obligations at the time and continued to keep their payments current. Bottom line: my credit score remains in the $600 \mathrm{~s}$ and $\mathrm{I}$ obtained a personal loan a few months ago through my credit union. My debts total under $\$ 8,000$, credit card included, so I am not doing wild spending nor living above my means. Currently, I rent, and I am happy to continue to do so for the foreseeable future.").

121. E-mail to author (Feb. 1, 2010, 15:55 MST) (on file with the SMU Law Review).

122. See Cong. Oversight Panel, supra note 96, at 12 (reporting that the self-cure rate for homeowners with prime loans who default on their mortgage dropped from an average of $45 \%$ between $2000-2006$ to $6.6 \%$ in 2009 -with current self-cure rates of $4.3 \%$ for Alt-A loans and $5.3 \%$ for subprime loans). 
financially destitute."123

Instead, they frequently look forward to the prospect of a brighter financial future: "I am absolutely thrilled about my future positive networth. ... My wife and I are extremely excited to finally have the answers we desperately needed to get out from under our lender's chokehold and secure a financially sound future for our family, more importantly our son." 124

\section{POLICY IMPLICATIONS}

The policy implications of this window into the emotional process of strategic default depend, in part, on answers to other questions, such as whether more strategic defaults would ultimately be good or bad for the economy and whether strategic default is an immoral or an acceptable response to the housing collapse. I have addressed these issues elsewhere. ${ }^{125}$

Assuming, however, that the government and lenders continue to wish to limit strategic default, several lessons can be drawn. First, deeply anxious underwater homeowners should be given real reasons to feel less apprehensive about their financial future if the government or lenders wish to induce them to continue making their payments. This might include, for example, the promise of a large incentive payment after a number of years ${ }^{126}$ or lenders agreeing to divert some nontrivial portion of

123. E-mail to author (Apr. 29, 2010, 22:33 MST) (on file with the SMU Law Review); see also E-mail to author (Jan. 16, 2010, 15:21 MST) (on file with the SMU Law Review) ("Our credit rating is now in the tank so we really have nothing else to lose and life will go on!").

124. E-mail to author (Feb. 1, 2010, 23:16 MST) (on file with the SMU Law Review); see also E-mail to author (Apr. 9, 2010, 20:40 MST) (on file with the SMU Law Review) ("We ... let our ... place go. Bought a great new place that may someday make back the $\$ 250 \mathrm{k}$ we sunk into the last one.").

125. See White, supra note 6, at 47-51 (arguing that an increase in the number of strategic defaults could be economically beneficial and deter undue risk-taking by lenders in the future); Brent T. White, The Morality of Strategic Default 1 (Ariz. Legal Studies, Discussion Paper No. 10-15, 2010) (arguing that strategic default can be the most moral and "responsible course of action when necessary" to protect the financial stability of one's family).

126. One such incentive program, designed by the Loan Value Group, has already been launched by one anonymous major investor in mortgages. The program called the Responsible Homeowner Reward program would give homeowners financial rewards for paying off their mortgages. See Press Release, Loan Value Group, Loan Value Group Launches RH Reward Program for Responsible Homeowners (Feb. 8, 2010), available at http:// www.marketwire.com/press-release/Loan-Value-Group-Launches-RH-Reward-ProgramResponsible-Homeowners-Major-US-Investor-1114113.htm. While there are in theory some great plusses to the incentive approach, the Loan Value Group program highlights a major concern as well: such programs are likely to be designed to play upon people's cognitive biases to keep them from defaulting when it may be financially wiser to default. See Edmans, supra note 5, at 2 . The Loan Value Group white paper discusses, for example, how homeowners' cognitive biases, such as the tendency to evaluate gains and losses separately and the endowment effect, can be used to make them likely to accept a lesser "reward" than they would accept as a principal reduction and then to hang on longer even when default is inevitable by any objective measure. Id. at 7-8. The Loan Value Group also provides a formula for calculating the smallest possible reward to maximize investor return. See id. at 11 . Despite these flaws, however, the Loan Value Group program is 
borrowers' mortgage payments into a retirement account. ${ }^{127}$

Second, many lenders' Kafkaesque loan-modification processes backfire in a significant number of cases and may be a contributing cause of the increase in strategic default. Moreover, once individuals actually make the psychological break to strategically default on their mortgages, there is little chance that they will self-cure. They also require considerably more in terms of lender concessions to induce them to resume some type of mortgage payment than it would have taken to convince them to continue to pay on the front end. ${ }^{128}$

Lenders might thus be better served by making early concessions to underwater homeowners. While early concessions would result in some homeowners getting relief when they could have been induced to continue making payments, it might also sharply reduce the number of strategic defaults and foreclosures, which are extremely costly to lenders. ${ }^{129}$

commendable in that it is an innovative, reward-based, rather than shame or fear-based, attempt to prevent strategic default.

127. A less benevolent approach has been at least hinted at by some economists: namely, lenders could increase the expected cost of default by pursuing more borrowers for deficiency judgments. See Sapienza \& Zingales, supra note 1 ("With more and more homeowners believing that lenders are failing to pursue those who default on their mortgages, there is a risk that a growing number of homeowners will walk away from their homes even if they can afford monthly payments."); Bhutta, Dokko \& Shan, supra note 8 , at 28 ("As the number of defaults and foreclosures reach record high levels, lenders may find it increasingly worthwhile to pursue deficiency judgments among borrowers, which would increase the potential legal liabilities of default.").

Responding to strategic default by pursuing more borrowers for deficiency judgments would, in essence, lock borrowers into a Catch-22 where they would be fearful for their financial future if they defaulted and fearful if they did not. The success of this approach would depend on making borrowers more afraid for their financial future if they defaulted than if they stayed in their deeply underwater homes. Not only could such a hardball approach be criticized for being unduly ruthless, but also it's based upon a fundamental lack of understanding of strategic default's emotional context-as it assumes that borrowers engage in a simple cost-benefit analysis. Thus, the reasoning goes, increase the cost of default and decrease its incidence. Such an approach also presupposes that borrowers default because they know that lenders are unlikely to pursue them for deficiency judgments and are thus not sufficiently fearful of default's consequences. To the contrary, the accounts of actual strategic defaulters demonstrate that they default despite being very fearful of the consequences, particularly in recourse states. See supra note 100 and accompanying text. More critically, while such an approach might work in with some homeowners, it's likely to backfire with others, especially to the extent that it increases their hopelessness and anger-which, as discussed above, are powerful drivers of default.

128. E.g., E-mail to author (Apr. 29, 2010, 22:33 MST) (on file with the SMU Law Review) ("After not paying my mortgage since last June, Wells Fargo actually got serious about settling the second mortgage for far less than the actual amount owed. They offered to settle for $50 \%$, then after more time I was offered a $20 \%$ settlement. I didn't agree to any of the offers. It is always fun to remind the agents calling that I offered to pay the entire debt had they given me a fixed rate loan. That must look like a really good offer about now, and it always leaves the agents without a canned reply.").

129. See Mortg. Bankers Ass'n, Lenders' Cost of Foreclosure 6 (2008), available at http://www.nga.org/Files/pdf/0805FORECLOSUREMORTGAGE.PDF. Some homeowners reported that the lenders pushed the homeowners to default, resulting in significant losses for the lender. E.g., E-mail to author (Apr. 30, 2010, 09:18 MST) (on file with the SMU Law Review) ("[We] were FORCED to walk away from our home and dreams. It has been $11 / 2$ years since we left our home and the house still sits vacant. It never ceases to amaze me that the bank would rather take our home then work with us to keep our family in it and continue to get some kind of payment each month. If they would 
Though the cost-benefit analysis for lenders has typically shown that it is better to take a small number of big losses on the back end than modify a large number of mortgages on the front end, this equation may begin to change (if it has not done so already) as more homeowners decide to strategically default.

Third, the government's policy of helping only homeowners who are already in default or "at risk of imminent default" absent some intervention sends the wrong message to other underwater homeowners. ${ }^{130}$ Indeed, rather than preventing a moral hazard, it arguably creates one. Most government programs, for example, only provide assistance to homeowners whose mortgages exceed $31 \%$ of their gross incomes. This includes both those whose mortgages were originally less than this amount but have now suffered income losses and those whose mortgages exceeded $31 \%$ of their incomes at origination. Those who took out more modest mortgages within affordability guidelines and have not suffered a decrease in income, however, are out of luck. Such an approach feels profoundly unfair to homeowners who believe that they "responsibly" bought less expensive and smaller houses than they might have liked and in which they are now stuck due to the housing-market collapse.

Moreover, if avoiding the creation of a moral hazard is a concern, ${ }^{131}$ then bailing out primarily underwater homeowners who took out mortgages disproportionate to their incomes or who have already defaulted on their mortgages would appear a misguided approach. This approach, combined with talk of personal responsibility, feels like hypocrisy and induces anger in many incipient defaulters who do not fall into these categories. This anger serves to relieve, or at least counteract, the guilt that might otherwise prevent some strategic defaulters from defaulting on their mortgages. ${ }^{132}$

have lowered our rate and done some kind of principle reduction we would be there continuing to make our payment to them. Because of the choice they made to turn us down for modification and short sale they will lose an estimated $\$ 250,000$ not including legal fees and vacancy loss.").

130. See Press Release, U.S. Dep't of the Treasury, supra note 79, at 3 (describing the HAMP program as designed to assist those at "at risk of imminent default").

131. In actuality, the government's approach appears to have little to do with helping homeowners who deserve it as opposed to those who do not-though frequently framed that way. The moral-hazard talk is mostly a distraction. The program is designed to minimize foreclosures. In practice, this means helping only people who are "at risk of imminent default," regardless of fault, and leaving the rest to fend for themselves. Id.

132. See Guiso, Sapienza \& Zingales, supra note 8, at 3 ("[A] policy aimed at helping people in arrears with their mortgage could have devastating effects on the incentives to strategically default of people who can afford to pay their mortgage if it is perceived to bail out people unjustly and thus undermine the moral commitment to pay."). Additionally, to the extent that homeowners feel that the government should help them, and it does not, they are likely to feel angrier and be more likely to strategically default. See id. at 19 ("[A] respondent view on whether the government should help homeowners becomes highly statistically significant. People who answer yes to that question are nine percentage points ( $35 \%$ of the sample mean) more likely to declare they want to do a strategic default when their negative equity equals $100 \mathrm{~K} . ")$. 
To defuse the anger and anxiety, the federal government should consider a broader approach to the negative-equity crisis. Others have already suggested several broad proposals, most of which involve principal reduction in some form. ${ }^{133}$ These proposals arise out of a growing consensus among academics that "negative equity alone" can trigger strategic defaults, and thus, principal reductions are necessary to stem their tide. ${ }^{134}$ This consensus has been derived, however, from studies that have not adequately considered strategic default's emotional context. Understanding this context suggests that the academic consensus may be wrong and that lenders may have gotten at least one thing right: principal reductions may not be necessary.

If the accounts in this article are representative, homeowners don't default just because they have negative equity. They default because they feel anxious and hopeless about their situations, which frequently include not only having hundreds of thousands in negative equity but also paying two or three times more as a mortgage payment than they would for rent, having little to no money to spare for savings, and sometimes needing to use credit cards just to stay afloat. These homeowners understandably feel that they are throwing money away on their underwater homes. ${ }^{135}$ After their lenders rebuffed them, these homeowners also frequently feel as though they are staring into a dark abyss. But all most need in order to hang on is some real hope that it's going to be okay in the long run.

One possible way to provide this hope would be a "rent-based loan

133. See, e.g., Rebel A. Cole, The Housing-Asset Relief Program: A Plan for Stabilizing the Housing and Securities Markets (DePaul University Departments of Finance \& Real Estate, Working Paper 2009) (proposing that " $\$ 300$ billion in TARP or stimulus funds ... be used to write down the principal on [underwater] mortgages"); Adam J. Levitin, Resolving the Foreclosure Crisis: Modification of Mortgages in Bankruptcy, 2009 WIS. L. REV. 565 565 (2009) (arguing for modification of home-mortgage debt in bankruptcy proceedings); Eric A. Posner \& Luigi Zingales, The Housing Crisis and Bankruptcy Reform: The Prepackaged Chapter 13 Approach 13 (University of Chicago Law \& Economics, Olin Working Paper No. 459, 2009) (proposing that the government force lenders to give underwater homeowners the option of resetting their mortgages to the current value of their houses in exchange for giving the lender $50 \%$ of the house's future appreciation).

134. See, e.g., Bhutta, Dokko \& Shan, supra note 8, at 2, 19 (arguing that "negative equity alone" can trigger mortgage defaults); Edmans, supra note 5, at 2 ("The source of the problem is the homeowner's balance sheet: since he has negative equity in his home, it is not worth keeping it by paying the mortgage."); Guiso, Sapienza \& Zingales, supra note 8 , at 7 ("[P]eople default because of the size of their negative equity, not just because they cannot afford to pay."); Foote, Gerardi \& Willen, supra note 8, at 1 (arguing that negative equity is a principal driver of default); Cole, supra note 133 (proposing principal writedowns); Levitin, supra note 133, at 565 (arguing for reduction of principal balances in bankruptcy proceedings); Posner \& Zingales, supra note 133, at 13 (proposing forced principal cram downs as necessary to curb strategic default); White \& Zingales, supra note 21 (supporting Zingales and Posner's proposal for forced principal reductions).

135. See, e.g., E-mail to author (Jan. 18, 2010, 19:50 MST) (on file with the SMU Law Review) ("we cannot rent the home for anywhere near enough to make the payment, so each month we are paying money out that we could use to help live on. We are both retired public school teachers ... and the money we are paying out could be used by us. ... At this point, we are pouring $\$ 600$ each month down a rat hole, money which we will most likely never get back, and all things considered, walking away sounds pretty good."). 
program."136 Such a program would give all underwater homeowners the option of refinancing their entire balances, regardless of loan-to-value, to interest rates that would bring their payments in line with the rental cost for comparable homes. ${ }^{137}$

A rent-based loan program would likely address the primary emotions associated with strategic default for many underwater homeowners because as long as their mortgage payments did not exceed the rent for comparable homes, they would not be "throwing their money away." They would be paying a fair price for a place to live. This would feel better. It would also address the major financial anxiety that drives many underwater homeowners to begin to contemplate default-the sense that they are squandering their financial resources by paying large mortgage payments instead of paying much less to rent. ${ }^{138}$

As long as homeownership felt like a good investment, many homeowners didn't mind paying much more in mortgage payments than they would to rent the same home. The difference was seen as forced savings. Indeed, the notion that homeownership was a good investment convinced many individuals to stretch to purchase homes during the housing boom in the first place. But once a homeowner is deeply underwater and feels a recovery is unlikely in the foreseeable future, paying extra for the mortgage no longer feels like an investment strategy-it feels like financial

136. This article's primary purpose is to describe the emotional process of default and not to advocate for any particular response. There are surely many ways to address the emotions that drive default. A "rent-based loan program" is just one possible responsethough, as I am about to explain, one with great promise.

137. In order to achieve this goal, interest rates would have be significantly reduced in many cases, frequently to as low as $2-3 \%$. These rates are not out of line, however, with interest rates associated with loan modification under HAMP. See CoNG. Oversight PANEL, supra note 96, at 52 (finding that the median interest rates of loans modified under HAMP declined from $6.85 \%$ to $2 \%$ ). Due to the perceived unfairness of subsidizing individuals who took out home equity loans to cover other expenses or to purchase other luxury items, the rent-based loan program could conceivably be limited to purchase money mortgages and non-cash out refinances. Modifying such mortgages would avoid this perception of unfairness because it would simply recognize that many underwater homeowners bought their homes at the wrong time-and were caught by an unprecedented housing collapse that was unforeseen by most of the nation's top economists, financial institutions, and government officials. See Michael J. Burry, Op-Ed., I Saw the Crisis Coming, Why Didn't the Fed?, N.Y. Times, Apr. 3, 2010, at WK10 (noting that Former Federal Reserve Chairman Alan Greenspan recently proclaimed that "no one could have predicted the housing bubble. 'Everybody missed it,' he said, 'academia, the Federal Reserve, all regulators." ). Because of this fact, modifying purchase money mortgages and non-cash out refinances runs little risk of creating a moral hazard and would not likely be seen as unfair to most people. Indeed, it may seem a more equitable approach to the public than expecting "responsible" underwater homeowners alone to carry the weight of the housing collapse on their shoulders.

138. Calculating comparable rent would be much like appraising a home-imprecise and within a range. But, because the anxiety of underwater homeowners is that they are grossly overpaying, anywhere close to comparable rent would be enough to relieve the sense of most incipient defaulters that they are throwing their money away. See, e.g., Email to author (Nov. 29, 2009, 19:57 MST) (on file with the SMU Law Review) ("They have outstanding credit and owe nothing other than the house in which they are upside down by nearly $\$ 200,000$. They have a monthly payment of $\$ 3,500$ and can rent the same house for about $\$ 1,000 . ")$. 
suicide. ${ }^{139}$

A rent-based loan program would eliminate this anxiety and, to the extent that the new mortgage was fully amortizing, put the homeowner in at least as good a position, if not better, than if he were renting. ${ }^{140}$ Additionally, even if a homeowner needed to relocate, the homeowner could rent his home for an amount that would cover his mortgage, thus relieving him of the anxiety that comes with losing money every month on a property that is already deeply underwater. In other words, a rent-based loan program would eliminate both the economic and the emotional incentives to default for, at the least, the types of strategic defaulters described in this article. ${ }^{141}$ Indeed, as evidence of this, these strategic defaulters did not generally demand principal reductions from their lenders but asked instead for reductions to their monthly payments. ${ }^{142}$

139. And, indeed, it might be financial suicide. The point is not that the feelings or actions of strategic defaulters are irrational. Anxious or angry people can make rational decisions. Acting to ameliorate unpleasant emotions can itself be rational. The point is that reducing strategic defaulters to emotionless rational actors misses the complexity of their decision-making processes-and may result in missing solutions to strategic default that are equally as effective and more palatable to lenders than large-scale principal reductions.

140. As a simple economic matter, this should eliminate the incentive to default. A "textbook premise in economics [is] that the price of a house, even an owner-occupied house, is the current value of the rent payments that could be earned from renting the property at market prices." Hye Jin Rho, Danilo Pelletiere \& Dean Baker, Ctr. for Econ. \& Policy Research, The Changing Prospects for Building Home Equity: An Updated Analysis of Rents and the Price of Housing in 100 MetropoliTAN AREAS 3 (2008). Moreover, "[t]he calculation for a rational homeowner in deciding whether to strategically default on a home mortgage is . . . the cost of renting [versus] the cost of continuing to own." White, supra note 6 , at 8 .

141. Whether there are other types of strategic defaulters who would not be sufficiently satisfied by this approach needs further study. It's possible that some homeowners default simply because they have negative equity, but it's doubtful that many, if any, would do so. Quantitative studies finding that negative equity alone can cause strategic default may have missed the connection between mortgage payments and comparable rent because they did not asked the question. For example, Bhutta, Dokko, and Shan found that negative equity alone can trigger mortgage defaults but apparently without considering rent-tomortgage payment ratios. See Bhutta, Dokko \& Shan, supra note 8 , at 2,9 . Similarly, Guiso, Sapienza, and Zingales asked homeowners whether they would default if they were $\$ 50,000, \$ 100,000$ or $\$ 200,000$ underwater-but did not ask those who said yes if they would make the same decision to default if their monthly mortgage payments were still less, or were reduced to less, than it would cost to rent a comparable home. See Guiso, Sapienza \& Zingales, supra note 8, at 9-10. This is not to criticize these excellent and informative studies, but to suggest a direction for further quantitative research.

142. E.g., E-mail to author (Dec. 20, 2009, 14:42 MST) (on file with the SMU Law Review) ("All I have asked for is a fixed rate loan-no modification to the mortgage value-and still the answer remains steadfastly 'NO.'"); E-mail to author (Dec. 10, 2009, $12: 29$ MST) (on file with the SMU Law Review) ("We bought a home in 2006 for $\$ 415 \mathrm{k}$, putting down $\$ 100 \mathrm{k}$. We recently tried to refinance to lower our fixed rate from 5.75 to 4.35 but were denied as the appraisal came in at only $\$ 220 \mathrm{k} . "$ ); E-mail to author (Nov. 30 , $2009,21: 49$ MST) (on file with the SMU Law Review) ("I've . . . asked both of my current mortgage holders if they would be willing to reduce the interest rate on my loan without any success."); E-mail to author (Nov. 29, 2009, 15:30 MST) (on file with the SMU Law Review) ("We have attempted to have our lender (WAMU, then Chase) modify our loan (1st and 2nd both with Chase), to no avail. Our mortgage payment is set to almost double next summer, and we have worked arduously to get something workable in advance of that avalanche."). 
A rent-based loan program might also be preferable to the current emphasis on short sales, as it would end the continued dumping of houses on the market at fire-sale prices and incentivize homeowners to hold on to their houses for the long-term. Indeed, because the new loans would not involve principal reductions, underwater homeowners would not have the option of dumping their houses on the market. Instead, they would have to hold on until the market recovered or until they paid down their loans. From many underwater homeowners' perspectives, having to hold on isn't such a bad thing though, as long as it doesn't risk financial ruin and there's a light at the end of the tunnel.

\section{CONCLUSION}

Regardless of how one feels about strategic default, homeowners who intentionally stop paying their mortgages are driven by the same basic emotions as everyone else. They aren't hyper-rational and they aren't immune from shame or guilt. Many are simply anxious and overwhelmed by a sense of hopelessness. They are also frequently angry at the perceived unfairness of their lender's and the government's unwillingness to help. It doesn't matter whether these emotions are justified or not; they are deeply felt and they are contributing factors in many underwater homeowners' decisions to intentionally default. Taking these emotions into account could not only suggest new directions for further quantitative research on strategic default but also lead to better economic understandings of strategic default and inform the development of more effective policies to stem its tide. 
Comments 


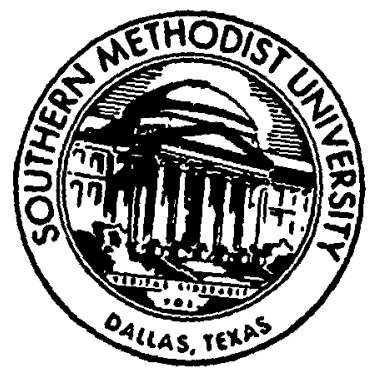

